Article

\title{
Energy Policy Concerns, Objectives and Indicators: A Review towards a Framework for Effectiveness Assessment
}

\author{
Dania Ortiz * and Vítor Leal *(D) \\ Faculty of Engineering, University of Porto (FEUP), Rua Dr. Roberto Frias, 4200-465 Porto, Portugal \\ * Correspondence: up201608014@fe.up.pt (D.O.); vleal@fe.up.pt (V.L.)
}

Received: 11 November 2020; Accepted: 5 December 2020; Published: 10 December 2020

\begin{abstract}
This work presents a review that aims to characterize the policy evaluation practices regarding the public policies on energy, with a focus on the metrics: concerns, objectives, and indicators. As key novelty, emphasis was put into finding attributes and metrics that can be used to assess effectiveness, not only efficacy or efficiency. The concerns and objectives were organized into four categories: Institutional, Environmental, Economic, and Social. For every category, detailed and condensed concerns were identified. It was attempted to find indicators for every condensed concern, which resulted in 15 core indicators.
\end{abstract}

Keywords: energy policy evaluation; energy policy effectiveness; energy policy indicators; energy planning; sustainability

\section{Introduction}

Differences among the policy objectives and the policy results are often found. This situation can be intensified if the energy policies (EP) are formulated or implemented, without considering the particular characteristics and capabilities of different countries or regions. EP evaluation has previously been proposed as a tool not only to compare the policy achievements with their objectives but also to assess the "goodness" of policy programs. This is becoming increasingly important as countries, regions, and even municipalities are pressed to develop carbon neutrality plans. Regardless of the jurisdiction, authorities are organizing to face the challenge of climate change mitigation. The efforts can be seen from top-level international agreements, as the Paris Agreement [1], and the Sendai Framework [2], to city-level climate-neutral plans (e.g., the plans developed in Berlin, Germany [3], Ann Arbor, USA [4], Bayside, Australia [5] or Freiburg, Germany [6]). Additionally, the United Nations 2030 Agenda [7] has established the Sustainable Development Goals (SDGs) as crosscutting international alignment principles. They represent a set of universal goals that meet the urgent environmental, political, and economic challenges facing the world. To meet these goals, Governments will need better planning tools and to monitor progress towards the targets; more specifically, tools that enable evaluating policies in multidisciplinary ways, allowing decision makers to analyze the policies in an integral way.

As an intended contribution to the planning and management of climate action plans, this work addresses the problem of EP evaluation, with a focus on effectiveness [8]. It starts with the conceptual differences between effectiveness, efficiency, and efficacy, and then moves on to find specific indicators for a comprehensive assessment. Such a set would be useful for ex-post evaluations, but in some cases, it could also be useful for ex-ante evaluation and thus assist the design of better policy programs. Therefore the main motivations of this work have been to create a support document that enables a more structured and comprehensive planning process (and that does not leave important aspects 
forgotten); planning programs that have a higher chance of succeeding, in practice; and supporting the good use of resources (public and/or private).

With the aim of evaluating EP and provide information that facilitates their adjustment to distinctive characteristics, a set of concerns was intended to be identified through this review. Concerns that were organized under the different proposed categories and subcategories. These concerns were organized under condensed concerns by identifying their final objective.

An indicator identification process was followed. Indicators were selected as the assessment metrics that can provide a comparison between the policies defined objectives and their achievement, therefore selected as an effectiveness measurement tool. The identification of concerns ends objectives has also been done through this report, serving as cornerstones for the identification of indicators.

The objective of this work was to review and systematize with a scientific-based methodology, the available information regarding EP effectiveness and its assessment indicators. The review led to the identification of trends in the subject. The main contribution of the document is the identification of the multidisciplinary attributes to assess energy policy effectiveness. No other review has been found available in the literature in which EP effectiveness is characterized holistically.

The paper is structured into 6 sections. Section 2 addresses the concepts of policy success: efficacy, efficiency, and effectiveness. The different EP effectiveness categories reported through the selected documents are presented in Section 3. Section 4 focuses on the systematization of energy policy concerns and objectives. Section 5 presents energy policy indicators, where the concerns of Section 4 have been matched with corresponding indicators. Section 6 includes a Discussion, and finally, the conclusions are presented in Section 7.

\section{Policy Success: Efficacy, Efficiency and Effectiveness}

A sensible goal of policy evaluation is to assess whether or not they are "successful". "Success" is defined as "the accomplishment of an aim or purpose" [9]. This is very much in line with the definition of "efficacy", which is defined as "the ability, especially of a medicine or a method of achieving something, to produce the intended result" [10].

A strict or "hard" approach to the evaluation of "success" or "efficacy" could therefore rely on the comparison between what is achieved and what was the target or goal; e.g., a program that has the target of promoting the installation of 80,000 solar collectors would be "successful" or "efficacious" if it achieves 80,000 or more installations, while it would be "unsuccessful" if it achieves equal or less than 79,999 installations.

The example above illustrates as well that such a "hard" approach to success evaluation is probably too strict. Under this approach, failing by a large amount or by a small amount is put under the same label. It could also serve as a stimulus to establish artificial and sometimes counter-productive low targets, to increase the probability of achieving the results.

Therefore, more flexible and comprehensive metrics are needed to assess policy success. This is where the concept of "effectiveness" may come into play. Although, sometimes seen as equivalent to "success", it is formally defined as "the degree to which something is successful in producing a desired result" [11]. The word "degree" opens room for a more gradual evaluation, clearly allowing for differentiation between failing by a large amount vs. failing by a small amount, as well as for succeeding by a small amount vs succeeding by a large amount.

Furthermore, "effective" has already been used, e.g., in the field of medicine as different from "effective" in the sense that it is something that is evaluated from the real-world use or implementation, including informal feedback from doctors and patients, rather than from controlled experiments alone [12].

It may be of interest to bring into consideration also the concept of "efficiency". This is clearly distinct from both efficacy as from effectiveness, assessing what was achieved concerning the means that were put into the program. While of course being efficacious is more important than being efficient, being efficient is also important. It implies that resources (e.g., funding to invest), which typically 
are limited, are being well used. By being efficient, more effect can be achieved from a given amount of resources.

As a more nuanced concept than efficacy, effectiveness thus has the potential to encompass the components of taking into consideration contextual variables and of assessing "success" in a quite modulated manner. It can even be advocated that, while privileging the evaluation of the achievement of results, a truly effective program should assess those results concerning the contextual variables (geographical, economic, and cultural) rather than by just comparing it to the initial goals of the program. This is so because these often are not declared and, even when they are, their choice is inherently somewhat arbitrary. Effectiveness can thus incorporate some dimension of efficiency into the assessment.

\section{Materials and Methods}

The academic databases Sciencedirect, Google Scholar, and JSTOR, together with the web browser Google were used for gathering documents. All the sources were useful to identify documents that characterize energy policy effectiveness. The expressions under which the search was done were "Energy policy evaluation" (academic and open-source); "Energy policy effectiveness" (academic source); "Energy policy assessment" (academic source); "Energy policy efficiency" (academic source). The selection of the documents to be reviewed was done by their title, abstract content, and keywords. After doing so, the criteria for the document selection for the analysis was having at least one concern that assesses energy policies. A summary of this process is presented in Table 1.

Table 1. Search terms by source and documents reviewed and adopted by each.

\begin{tabular}{cccc}
\hline Search Term & Source & Documents Reviewed & Documents Adopted \\
\hline Energy Policy Evaluation & Sciencedirect & 18 & 9 \\
Energy Policy Evaluation & Google & 17 & 10 \\
Energy Policy Assessment & Sciencedirect & 16 & 10 \\
Energy Policy Effectiveness & Sciencedirect & 9 & 5 \\
Energy Policy Effectiveness & Google Scholar & 20 (3 repeated) & 15 \\
Energy Policy Effectiveness & JSTOR & 5 & 3 \\
Energy Policy Evaluation & Google Scholar & 19 (3 repeated) & 13 \\
Energy Policy Evaluation & JSTOR & $5(1$ repeated) & 1 \\
\hline
\end{tabular}

The detail of each search source is presented in Appendix A, for which reference and order numbers have been provided and that have been used for the organization and analysis of the documents presented in the document.

\section{Analysis: Geographical Scope}

When analyzing the scope or level of application of the energy policies evaluations (local, regional, national, international, or a combination among them), it is noted in Table 2 that the highest number of the reviewed documents regards the national level (with 40 documents), with a considerable difference above the other alternatives. The national scope is followed by the international scope (with eleven documents). Some documents regard all the levels of application or a combination of more than one level. Another observation is that only three locally focused documents were found.

Concerning the time frame shown in Table 3, almost all of the retrieved documents state or enabled us to infer the period of the evaluation (summing 53 documents), against 13 documents where that was not possible. The time framing of the process, according to the reviewed documents, can be ex ante, in progress, or ex post. The ex post energy policy evaluation approach was the most often found ( 34 documents), followed by the ex ante approach (10 documents). It can be noticed that only two of the reviewed documents ("Moving Toward Energy Efficiency: A Results-Driven Analysis of Utility-Based Energy Efficiency Policies", Theel and Westgaard, 2017 [13] and "Evaluating Consistency 
in Environmental Policy Mixes through Policy, Stakeholder, and Contextual Interactions Lieu et al., 2018 [14] declared a combined approach (with more than one possible timing period).

Table 2. Energy policy evaluation documents found per geographical level of analysis.

\begin{tabular}{ccc}
\hline Level & Quantity & Document Numbers (from Tables in Appendix A) \\
\hline National & 40 & $1-4 ; 6-11 ; 13 ; 16-18 ; 20 ; 21 ; 24-26 ; 28 ; 30-32 ; 34 ; 35 ; 45 ; 46 ; 50 ; 52 ;$ \\
Regional (State) & 9 & $53-55 ; 58-64 ; 66$. \\
International & 11 & $14 ; 15 ; 19 ; 27 ; 36 ; 38 ; 39 ; 47 ; 56$. \\
Combined & 3 & $29 ; 33 ; 37 ; 40 ; 41 ; 43 ; 44 ; 49 ; 51 ; 57 ; 65$. \\
Local & 3 & $12 ; 23 ; 22$. \\
\end{tabular}

Table 3. Energy policy evaluation documents found per time-frame.

\begin{tabular}{ccc}
\hline Time Framing of the Process & Quantity & Documents Numbers (from Tables in Appendix A) \\
\hline Ex ante & 10 & $1 ; 5 ; 15 ; 22 ; 23 ; 29 ; 31 ; 40 ; 47 ; 51$. \\
Ex post & 34 & $4 ; 8-10 ; 18 ; 21 ; 27 ; 32 ; 33 ; 35 ; 36 ; 38 ; 39 ; 41-63 ; 65 ; 66$. \\
In progress & 7 & $19 ; 28 ; 30 ; 34 ; 46 ; 48 ; 64$. \\
Combined & 2 & $14 ; 17$. \\
Not inferred & 13 & $2 ; 3 ; 6 ; 7 ; 11-13 ; 16 ; 20 ; 24-26 ; 37$. \\
\hline
\end{tabular}

Table 4 shows the participation of stakeholders in the EP evaluation. Stakeholder participation is related to the involvement of actors along the evaluation process. Less than one-third of the documents retrieved report some form of participation from stakeholders (19 out of 66 documents).

Table 4. Energy policy evaluation documents found per stakeholder participation.

\begin{tabular}{ccc}
\hline Stakeholder Participation & Quantity & Documents Numbers (from Tables in Appendix A) \\
\hline Yes & 19 & $3-6 ; 13 ; 14 ; 17 ; 20 ; 23 ; 29 ; 30 ; 37 ; 40 ; 53 ; 54 ; 58 ; 59,64$. \\
\hline \multirow{2}{*}{ No } & 47 & $1 ; 2 ; 5-12 ; 16 ; 18 ; 19 ; 21 ; 22 ; 24-28 ; 31-36 ; 38 ; 39 ; 41-52 ; 55-57 ;$ \\
& & \begin{tabular}{c}
$60-63 ; 65 ; 66$. \\
\hline
\end{tabular}
\end{tabular}

The methodological approaches for evaluation were also reviewed and are presented in Table 5. As expected, very diverse approaches were found from document to document. The qualitative-based methodology was found as the most popular approach (19 documents). Descriptive and qualitative analysis methods have been considered as qualitative-based. The second more frequent approach is statistical (17 documents). Scenario and modeling techniques have also been identified (12 documents). The category others include the approaches that were found only once e.g., cost-benefit analysis (CBA), return on assets (ROA), etc.

Table 5. Energy policy evaluation documents found per methodological approach.

\begin{tabular}{ccc}
\hline Methodology & Quantity & Documents Numbers (from Tables in Appendix A) \\
\hline Statistical & 17 & $10 ; 14 ; 20 ; 27 ; 32 ; 33 ; 36 ; 38 ; 39 ; 42-44 ; 48 ; 52 ; 56 ; 61 ; 63$. \\
Scenario & 12 & $1 ; 5 ; 9 ; 16 ; 18 ; 21 ; 22 ; 34 ; 53 ; 60 ; 65 ; 66$. \\
Qualitative-based approach & 19 & $2-4 ; 11 ; 13 ; 17 ; 23-25 ; 28 ; 31 ; 37 ; 40 ; 41 ; 45 ; 46 ; 57 ; 58 ; 64$. \\
Indicators & 4 & $8 ; 12 ; 35 ; 59$. \\
Others & 14 & $6 ; 7 ; 15 ; 19 ; 26 ; 29 ; 30 ; 47 ; 49-51 ; 54 ; 56 ; 63$. \\
\hline
\end{tabular}

In Table 6, it can be seen that when analyzing the motivation stated in the reviewed documents, the most common one is to conduct a policy evaluation itself, observed in 34 documents. Four documents clearly defined their interest in supporting policymakers, while 16 documents target the evaluation of policy success. It can be noted the interrelation between the identified motivations. 
Table 6. Energy policy evaluation documents found per expressed objectives.

\begin{tabular}{ccc}
\hline Motivation & Quantity & Documents Numbers (from Tables in Appendix A) \\
\hline Policy evaluation & 34 & $6-8 ; 13-16 ; 18-22 ; 27 ; 30 ; 32-34 ; 37 ; 39 ; 40 ; 45 ; 46 ; 49 ;$ \\
Policy review & 7 & $53-55 ; 57-62 ; 64-66$. \\
Support policy makers & 4 & $23 ; 24 ; 26 ; 29 ; 35 ; 36 ; 51$. \\
Evaluate policy success & 16 & $3 ; 5 ; 17 ; 20$. \\
Creation of a methodology/framework & 5 & $1 ; 9-12 ; 38 ; 41-44 ; 47 ; 48 ; 50 ; 52 ; 56 ; 63$. \\
\hline
\end{tabular}

\section{Results}

\subsection{Energy Policy Concerns and Objectives}

The identification of the concerns most frequently included in the literature and how they are defined led to forming a list of more than 60 concerns. They have been classified into four broader categories, and some subcategories have been formed.

\subsubsection{Environmental Concerns}

As shown in Table 7, two subcategories were defined: greenhouse gas (GHG) and other environmental impacts. The burden among the categories could be very thin, as some concerns are related to both, as renewable energy (RE) sources related concerns (e.g., RE standards, RE Deployment and RE Tech Efficiency).

Table 7. Energy Policy Environmental concerns found.

\begin{tabular}{|c|c|c|}
\hline Document & GHG & Other Impacts \\
\hline Lieu et al., 2018 [14]. & - & Environmental stakeholders \\
\hline Abotah, 2015 [15]. & Low carbon economy & Environmental protection \\
\hline Chapman et al., 2016a [16]. & GHG emissions & RE Deployment, RE Tech Efficiency \\
\hline Chapman et al, 2016b [17]. & GHG emissions & - \\
\hline Chen, 2011 [18]. & - & Eco-label system \\
\hline Alyamani et al., 2016 [19]. & GHG emissions & - \\
\hline Lee \& Shih, 2010 [20]. & - & Environmental protection \\
\hline Nikolaev \& Konidari, 2017 [21]. & GHG emissions & 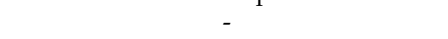 \\
\hline Hafeznia, Aslani, Anwar, \& Yousefjamali, 2017 [22]. & - & Climate information \\
\hline S. J. Li et al., 2017 [23]. & - & RE energy production \\
\hline Yu et al., 2015 [24]. & $\mathrm{CO} 2$ emissions & Energy savings \\
\hline Aized et al., 2018 [25]. & GHG emissions & - \\
\hline Arababadi et al., 2017 [26]. & GHG emissions & - \\
\hline Burke \& Stephens, 2017 [27]. & - & RE minimum requirements \\
\hline Chang \& Fang, 2017 [28]. & - & Sustainability in energy supply \\
\hline García-Álvarez et al., 2018 [29]. & - & General environmental awareness \\
\hline Mirjat et al., 2017 [30]. & - & General environmental awareness \\
\hline Atalla et al., 2018 [31]. & Climate change mitigation & - \\
\hline Delmas \& Montes-sancho, 2011 [32]. & GHG emissions & Renewable resources \\
\hline Menz \& Vachon, 2006 [33]. & - & Resources capacity and quality \\
\hline Arbolino et al., 2019 [34]. & GHG emissions & Renewable share \\
\hline Thornley \& Cooper, 2008 [35]. & - & Resource capacity \\
\hline Jenner et al. 2013 [36] & - & Resources share \\
\hline Dong, 2012 [37]. & GHG emissions & - \\
\hline Sancho, 2010 [38]. & GHG emissions & - \\
\hline Bersalli, et al., 2020 [39]. & GHG emissions & - \\
\hline Stagl, 2006 [40]. & Global warming and climate change & $\begin{array}{c}\text { Renewable energy use; Less-pollutant } \\
\text { transportation }\end{array}$ \\
\hline Hoffman et al., 1977 [41]. & GHG emissions & Environmental impact, energy resources \\
\hline Carley, 2009 [42]. & - & Natural resource endowments, RE share \\
\hline Kilinc-Ata, 2016 [43]. & GHG emissions & - \\
\hline
\end{tabular}

Greenhouse gas (GHG) emissions reduction was found as the predominant concern for evaluating energy policies under an environmental perspective and gathered under the subcategory Environmental-GHG. The GHG emissions concern consideration has been incentivized by the continuous and reinforced influence produced by the definition of international agendas, 
national targets, agreements, and other international efforts to reduce GHG emissions and minimize climate change.

Other impacts include the concerns that assess the conservation and improvement of the environment, excepting GHG. RE related concerns (e.g., RE standards, RE Deployment and RE Tech Efficiency) have been included in this subcategory.

\subsubsection{Economic Concerns}

A large set of concerns was found under the economic category, as shown in Table 8. It should be noticed that almost all the reviewed documents included at least one aspect under this category. The economic dimension regards all the concerns that assess policies in monetary terms, from which two subcategories were formed.

Table 8. Energy Policy Economic concerns found.

\begin{tabular}{|c|c|c|}
\hline Document & Cost & Competitiveness \\
\hline Chapman et al., 2016a [16]. & Energy price performance & Market growth and maturity \\
\hline Theel \& Westgaard, 2017 [13]. & Energy price and demand & GDP \\
\hline Abotah, 2015 [15]. & Economic feasibility & - \\
\hline Qiang et al., 2016 [44]. & Cost-Effectiveness & - \\
\hline Lieu et al., 2018 [14]. & $\begin{array}{l}\text { Supply chain Stakeholders and } \\
\text { Service providers }\end{array}$ & - \\
\hline Chapman et al., 2016b [17]. & $\begin{array}{l}\text { Generation Cost, Electricity Price } \\
\text { Impact, Levelized cost of electricity } \\
\text { (LCOE) }\end{array}$ & GDP Impact and Market Impact \\
\hline Energy and Environmental Economics, 2014 [45]. & Net Cost & - \\
\hline Chen, 2011 [18]. & Energy demand, energy price & - \\
\hline Bukarica \& Tomšić, 2017 [46]. & $-4 \cos 20$ & Market barriers \\
\hline Alyamani et al., 2016 [19]. & Energy demand, cost, and price & Utility profits and revenue \\
\hline Lee \& Shih, 2010 [20]. & 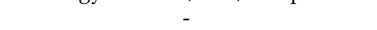 & Macroeconomic parameters \\
\hline Collado \& Díaz, 2017 [47]. & Energy savings & 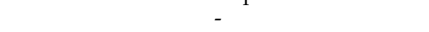 \\
\hline Nikolaev \& Konidari, 2017 [21]. & Internalized total cost & Attractiveness in RES investment \\
\hline A.J. Chapman [48]. & Generation Cost, Electricity Price & GDP Impact and Market Impact \\
\hline X. Zhao et al., 2016 [49]. & $\begin{array}{l}\text { Power demand, energy substitution, } \\
\text { technological change }\end{array}$ & 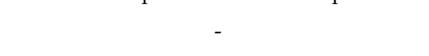 \\
\hline S. J. Li et al., 2017 [23]. & Economic data & - \\
\hline S. Ma et al., 2020 [50]. & Carrier price, demand & Patents \\
\hline Shrimali et al., 2017 [51]. & Cost-effectiveness potential & Investment incentives \\
\hline Aized et al., 2018 [25]. & Costs, supply, and demand & - \\
\hline Burke \& Stephens, 2017 [27]. & Financial measures & - \\
\hline Chang \& Fang, 2017 [28]. & Economic context & - \\
\hline Liu et al., 2018 [52]. & Costs and profits & - \\
\hline García-Álvarez et al., 2018 [29]. & $\begin{array}{l}\text { Electricity price trends, economic } \\
\text { situation, security of supply }\end{array}$ & - \\
\hline Mirjat et al., 2017 [30]. & Economic efficiency & - \\
\hline Atalla et al., 2018 [31]. & Welfare and Economic impact & - \\
\hline Lund, 2007 [53]. & Cost-effectiveness & Market State \\
\hline Dong, 2012 [37]. & $\begin{array}{l}\text { GDP per capita, Oil imports, } \\
\text { electricity consumption }\end{array}$ & 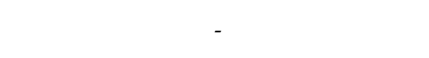 \\
\hline Agnolucci, 2007 [54]. & Financial support & - \\
\hline Mitchell et al., 2006 [55]. & Risk reduction & - \\
\hline Sancho, 2010 [38]. & GDP & - \\
\hline Qiu et al., 2019 [56]. & City Infrastructure & - \\
\hline Bersalli et al., 2020 [39]. & $\begin{array}{l}\text { Energy Production, Energy } \\
\text { dependence rate }\end{array}$ & Access to domestic credit, Income per capita \\
\hline Economics, 2011 [45]. & Cost-effectiveness & - \\
\hline Yuan et al., 2011 [57]. & Cost-effectiveness & \\
\hline Rosenow 2016 [58]. & Energy Savings & - \\
\hline Nicholson-crotty \& Carley, 2016 [59]. & Energy generation & - \\
\hline Stagl, $2006[40]$ & Energy efficiency; energy costs & - \\
\hline Zhang et al., 2014 [60]. & $\begin{array}{l}\text { Energy costs, renewable energy costs } \\
\text { (and subsidies), Carbon prices }\end{array}$ & - \\
\hline Hoffman et al., 1977 [41]. & $\begin{array}{c}\text { Cost, generation, dependence on } \\
\text { imports }\end{array}$ & - \\
\hline Carley, 2009 [42]. & $\begin{array}{l}\text { Gross state product per capita, } \\
\text { electricity use, electricity price }\end{array}$ & - \\
\hline Neij \& Kerstin, 2006 [61]. & $\begin{array}{l}\text { Technology characteristics, electricity } \\
\text { costs }\end{array}$ & - \\
\hline J. Zhao et al., 2011, [62]. & Technology payback period & - \\
\hline Kilinc-Ata, 2016 [43]. & $\begin{array}{l}\text { Carrier prices, imports, GDP growth, } \\
\text { electricity consumption }\end{array}$ & - \\
\hline Verbruggen, 2009 [63]. & Cost-effectiveness & - \\
\hline Banerjee \& Solomon, 2003 [64]. & - & $\begin{array}{l}\text { Consumer response and } \\
\text { manufacturer/marketer response }\end{array}$ \\
\hline Kim \& Lee, 2012 [65]. & - & $\begin{array}{l}\text { Consumer choice, technology, } \\
\text { and location characteristics }\end{array}$ \\
\hline
\end{tabular}


The Economic-cost subcategory includes the concerns related to direct monetary influence, particularly related to costs and expenses. Both levels, macroeconomic and microeconomic, have been assessed; e.g., the energy price is included, referring to the economic aspects in a micro economical view. The gross domestic product (GDP) impacts of energy decisions refer to the macro level of an economy.

Regarding Economic-competitiveness, this subcategory brings together market orientation concerns (e.g., attractiveness of investment, market growth and market maturity aspects). The market characteristics provide information that allows the comparison among different markets, informing about their national and international competitiveness.

\subsubsection{Social Concerns}

Regarding the Social category, all concerns with a social orientation have been gathered in Table 9, including the concerns in which equity is recognized. Two sub-categories were defined. Firstly, Social-equity include concerns related to social sustainability factors, as the acceptance of certain energy technologies and the impacts of subsidies on energy bills. It can be noticed how equity has been considered in several documents, being a key component of distributive energy justice, and that should contribute to new policy initiatives. Some other concerns include energy democracy, energy equity and consumer surplus. This last is an important reference to measure the welfare of consumers [29].

Table 9. Energy Policy Social concerns found.

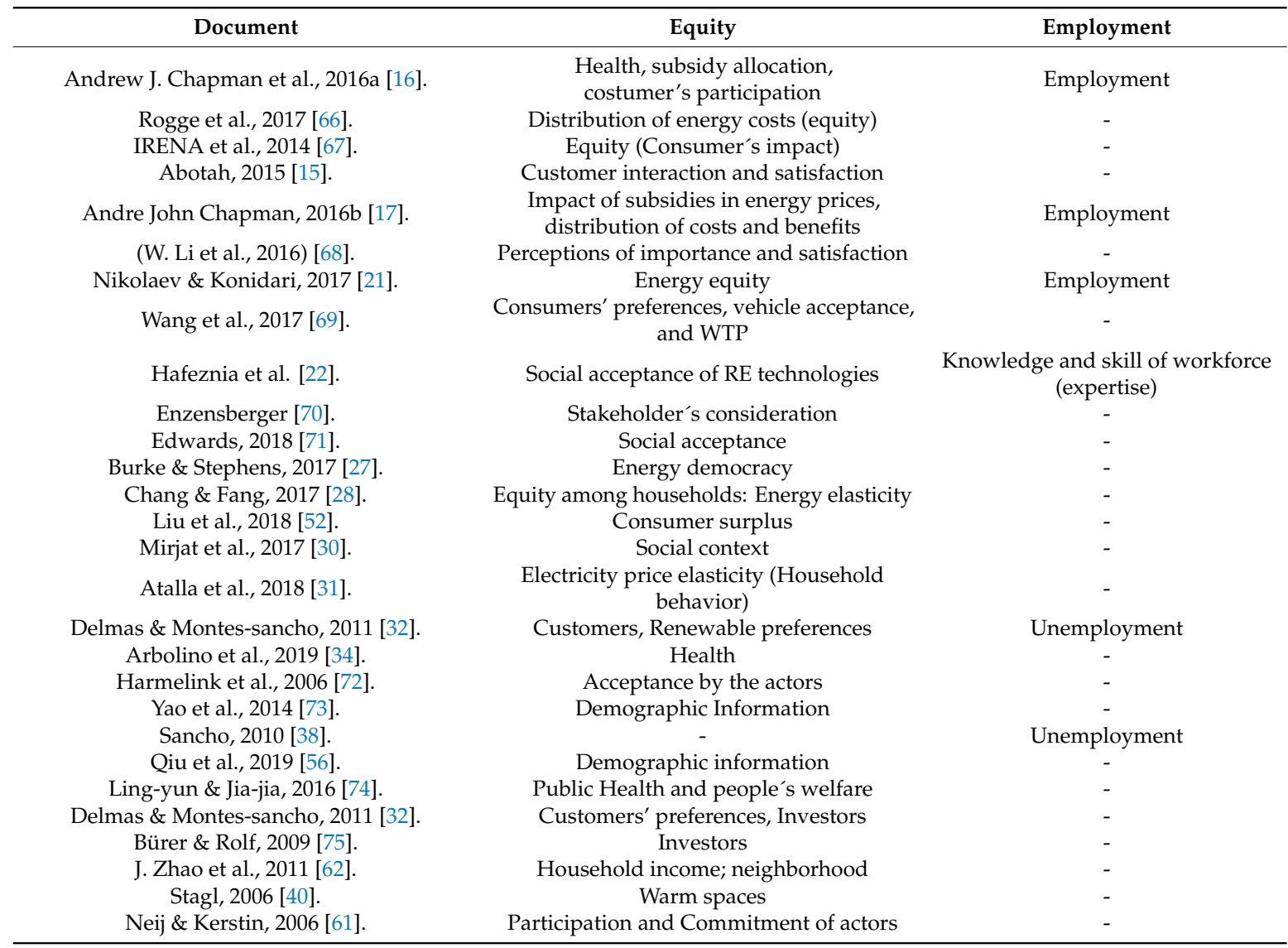

The second subcategory, Social-employment, as can be inferred from its name, is the subcategory to account for the employment rates affected by the energy policies. The knowledge and skills (expertise) of the workforce have also been included in this subcategory. 


\subsubsection{Institutional Concerns}

Finally, under the institutional concerns assessment (Table 10), the variety of concerns found through the reviewed papers was larger than in the previous categories; however, no subcategories were created, due to a lack of a clear structure. The identified concerns describe the policy institutional framework, including concerns as flexibility with policy instruments, actors, and institutional environment, among others.

Table 10. Energy Policy Institutional concerns found.

\begin{tabular}{cc}
\hline Document & Concern \\
\hline Rogge et al., 2017 [66]. & Actor's and institution's participation \\
IRENA et al., 2014 [67]. & Political accountability, source of finance and regulatory simplicity \\
Andrew J. Chapman et al., 2016c [76]. & Governance, policy processes and priorities \\
Theel \& Westgaard, 2017 [13]. & Policy Environment \\
Abotah, 2015 [15]. & Institutional and Government support \\
Bukarica \& Tomšić, 2017 [46]. & Political will, public participation, public dialogue, \\
Yoon \& Sim, 2015 [77]. & regulatory framework \\
Nikolaev \& Konidari, 2017 [21]. & Policy framework (policy environment and policy process) \\
Arababadi et al., 2017 [26]. & Administrative and financial capacity, Feasibility of implementation \\
Burke \& Stephens, 2017 [27]. & Policy budget \\
Liu et al., 2018 [52]. & Policy implementation mechanisms \\
García-Álvarez et al., 2018 [29]. & Government fiscal revenue \\
Mirjat et al., 2017 [30]. & Policy Environment \\
Delmas \& Montes-sancho, 2011 [32]. & Policy Environment \\
Menz \& Vachon, 2006 [33]. & Type of Governor \\
Dong, 2012 [37]. & Policy regime \\
Agnolucci, 2007 [54]. & Other policies (number) \\
Qiu et al., 2019 [56]. & Policy options \\
Rosenow et al., 2016 [58]. & Policy characteristics \\
Carley, 2009 [42]. & Policy process \\
Harmelink et al., 2008 [78]. & Portitical (instints \\
J. Zhao et al., 2011 [62]. & Subsidies \\
S. Ma et al., 2020 [50]. & Robustness, efficiency \\
Verbruggen, 2009 [63]. &
\end{tabular}

There is a recent recognition of the importance of the institutional context. Concerns like political commitment, policy choice, and citizen engagement characterize policies from an institutional perspective.

Even if the institutional performance does not measure policy success itself, it contributes to explain the policy environment. Institutional context tends to be assessed qualitatively rather than quantitatively. The lack of quantitative procedures to evaluate some dimensions of the institutional context provides the opportunity to develop scientific-based methodology proposals that enable to evaluate the concerns found under this category.

Table 11 shows the number of appearances per concern by subcategory. It is noted that Economic-cost is the subcategory that was found more often in the reviewed documents, reflecting the importance given to it by the consulted sources. The second most popular subcategories are Governance and Social equity, which regards the energy impacts on society and energy distributional impacts.

Table 12 shows an analysis of the categories. It was noted that most documents mention more than one category (42 documents). From the remaining 24 documents (single category approach), 12 documents report an Economic orientation, being the largest one.

\subsection{Identification of Gaps}

After the review of the concerns that have been used to characterize the effectiveness of the energy policies, some areas have been identified as not fully covered regarding an integral review of EP effectiveness characterization. 
Table 11. Number of appearances per concern by subcategory.

\begin{tabular}{ccc}
\hline Category & Quantity of Documents & Documents Numbers (from Tables in Appendix A) \\
\hline Environmental-others & 14 & $2,7,15,17,18,21,24,25-29,31,33$ \\
Environmental GHG & 14 & $1,5,9,15,18,21-23,36,38,39,44,47,49$ \\
Economic-cost & 36 & $1,2,5,8-10,14-19,22,24-29,31,32-36,39,40,42-49$, \\
Economic-competitiveness & 15 & 60 \\
Social Equity & 25 & $1,3,5,7,9,10,14,18,31,34-37,49,62$ \\
Social-Employment & 7 & $1,6,9,11,12,15,18,20,24-26,28,29,31,36,37,39,40$, \\
Governance & 26 & $42,48,52,53,58,60,66$ \\
& & $1,9,10,18,31,36,47$ \\
& & $6,4,9-15,23,24,26-28,36,38,40,44,45,48,51,56,57$, \\
\end{tabular}

Table 12. Single vs. multi-category orientation.

\begin{tabular}{ccc}
\hline Category & Quantity of Documents & Documents numbers (from Tables in Appendix A) \\
\hline Single & 24 & $4,6-8,13,16,19-21,30,32,34,37,41,42,46,50,52,54,57,58$, \\
& & $61,64,66$ \\
Multi-category & 42 & $1-3,5,9,10-12,14,15,17,18,22,23,24-29,31,33,35,36$, \\
Environmental & 2 & 21,41 \\
Economic & 12 & $78,40,45,47-49,51-53,55,56,59,60,62,63,65$ \\
Social & 7 & $7,8,16,19,32,34,46,50,52,54,61,64$ \\
Institutional & 3 & $6,20,30,37,42,58,66$ \\
\end{tabular}

A list of missing concerns has been elaborated (Table 13) in which additional concerns have been included. The criterion followed to add concerns was if the outcomes of the concern could be modified by a policy and their relevance for the ep effectiveness characterization.

Table 13. Additional concerns by category.

\begin{tabular}{ccc}
\hline Environmental Concerns & Economic Concern & Institutional Concern \\
\hline Water resources & Externalities pricing & Amount and quality of Staff \\
Land resources & Grid state & - \\
Waste Management & - & - \\
\hline
\end{tabular}

Not all the subcategories needed extra concerns, e.g., the Social subcategories (Social-Equity and Social-Employment) have been considered as complete, as the concerns identified through the review do provide a wide perspective of the social approach.

Under the environmental category, the concern of environmental protection has been often found through the revised documents. However, it has been considered relevant to detail it through more specific concerns (as water and land resources) to be able to better measure them. They are relevant concerns for the environmental evaluation of policy and closely related to the impacts of energy on the environment.

The externalities pricing is a concern that can be reported under the environmental or economic category, due to their interrelationship in the concern itself. For the monetarization process that externalities involve, it has been decided to keep this concern under the economic category.

It was found a lack of consideration of some aspects that may be relevant for the policy appraisal, as available funds (for technology, innovation, and infrastructure investment), the economic situation of the private sector, and the economic situation by regions, economic and fiscal parameters (like inflation, escalation, exchange rates, and taxes). All these concerns can be gathered as economic background. Additionally, the grid state is a relevant concern for its relation to the energy service provision.

Finally, the concern under the institutional category (Amount and quality of Staff) intends to involve a relevant aspect of the institutional framework: the governing human resources. They differ from Knowledge and skill of the workforce (reported in the Social concerns), as this last regards 
the technical workforce involved in the policy implementation, while the second one, regards the governance-related workforce.

\subsection{Inferred Energy Policy Objectives and Condensed Concerns}

With the intention of better organizing the concerns and facilitating the identification of their evaluation metrics, a condensation process was taken to eliminate redundancies, conglomerating them into condensed concerns. The condensed concerns have been identified after questioning where there could be an impact if the extracted concern does not comply. In addition, for every condensed concern, its end objective has been identified (as shown in Figure 1). The identification of the ends objective aims to put the review more in line with the typical multi-criteria decision making (MCDM) language and to ease the further identification of indicators.
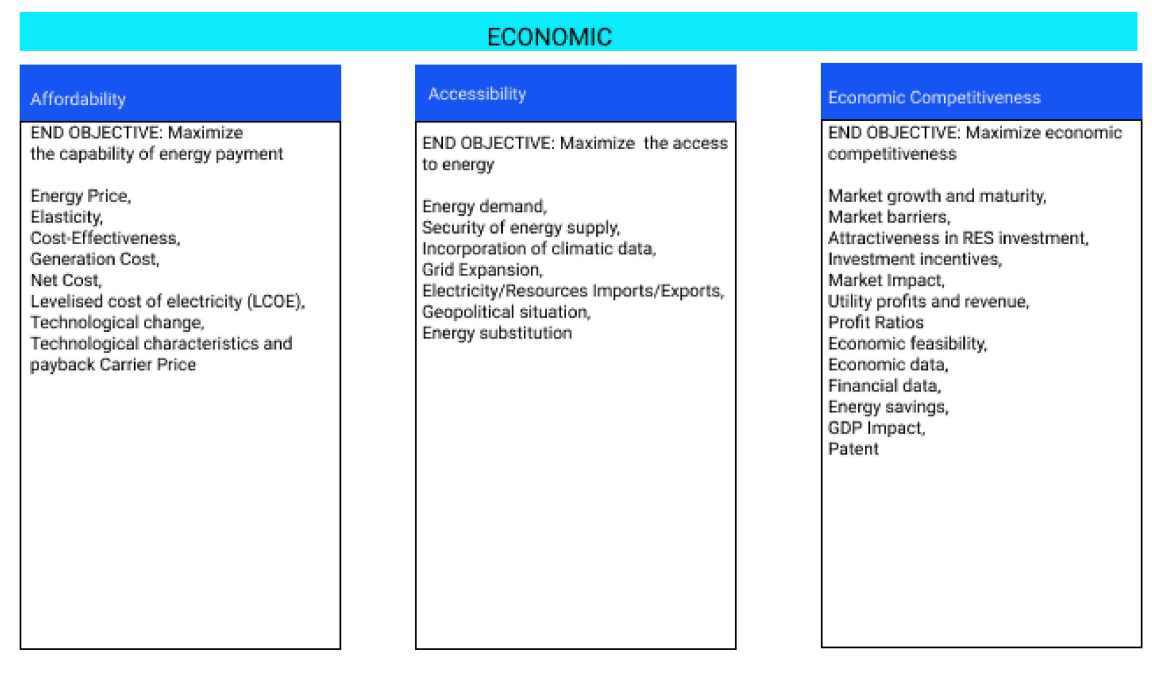

\section{INSTITUTIONAL}

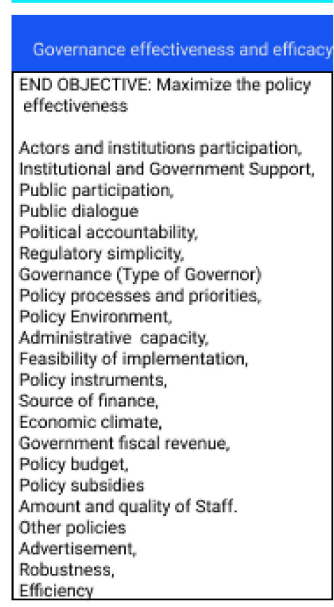
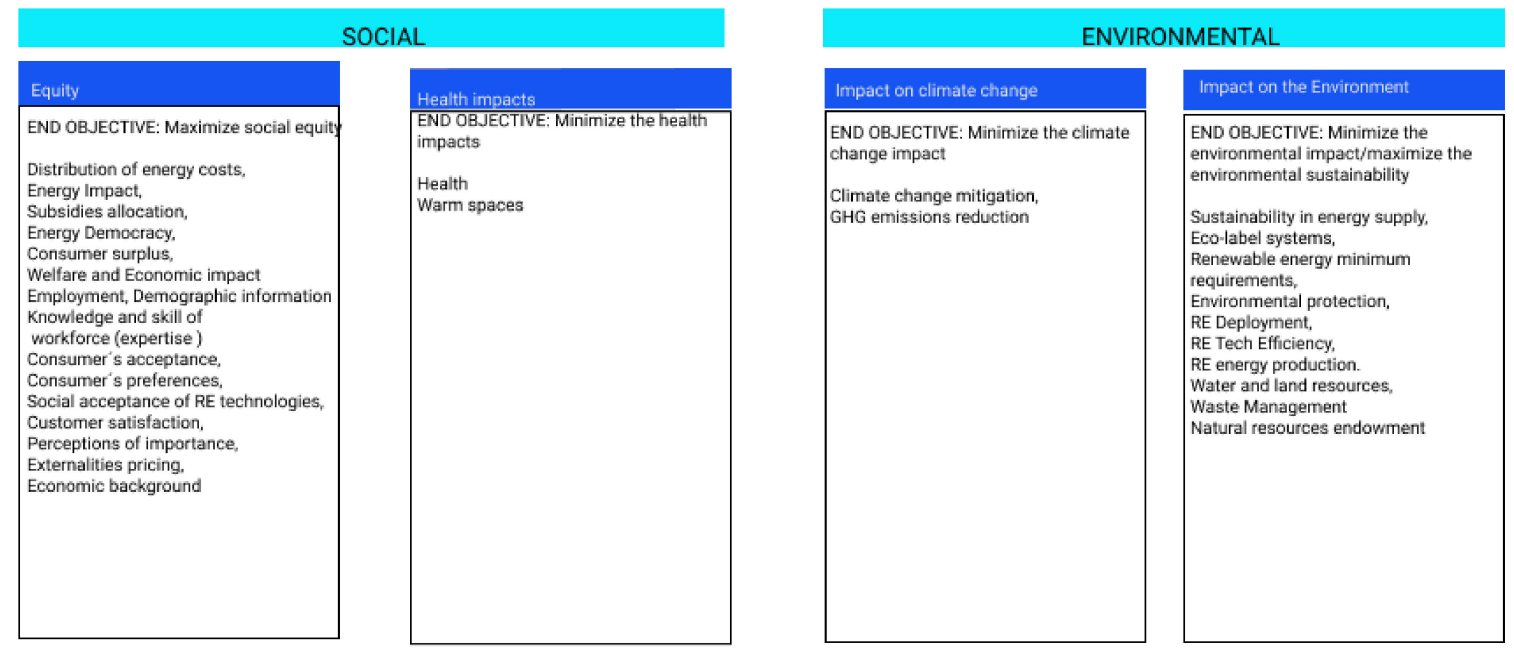

Figure 1. Extracted and condensed concerns per ends objective.

The economic extracted concerns are the largest in number when compared with other categories. It was possible to narrow down the initial list to three condensed concerns: affordability, accessibility, and economic competitiveness.

Affordability includes all the concerns that may affect the state of being cheap enough for people to be able to pay for electricity or other forms of energy [79]. Accessibility refers to the fact of energy or electricity being able to be reached or obtained easily [80].

Competitiveness brings together the concerns that relate to being able to compete successfully with other companies, countries, organizations, etc. [81]. 
The concerns under the environmental spectrum have been condensed through two concerns. The first one reflects the policy's impact on the environment. Its ends objective relates to environmental sustainability, defined as the quality of causing little or no damage to the environment and therefore able to continue for a long time [82]. The second condensed concern denotes the impacts on climate change.

In the social category, Equity, as the situation in which everyone is treated fairly and equally [83], gathers the majority of the social concerns. Health is however kept as a separated condensed concern.

Governance effectiveness and efficacy as a single condensed concern included all the concerns under the institutional perspective. Governance is defined as how an organization is managed at the highest level and the systems for doing so [84] and assessed through its effectiveness and efficacy.

The organization of the extracted and condensed concerns is documented in Figure 1 The economic, environmental, and social categories include more than one condensed concern.

\section{Indicators for Energy Policy Effectiveness}

\subsection{Indicators' Relevance and Types}

The relevance of indicators has been recognized in the energy field [85-89]. Agents have created ways to assess different dimensions of the energy industry through indicators, giving them several functions and purposes [90-93]. They can be used as assessment metrics, providing a comparison between the defined objectives and their achievement, therefore assessing the effectiveness of the state of systems, which can be applied to assess the success of policies.

Indicators can be differentiated by function, serving as monitoring, guideline, or communication instrument. With a monitoring purpose, indicators evaluate the policy progress towards their objective's achievement. When indicators are used to monitor the status of an energy policy, they can be helpful for the improvement of the policy. An in progress evaluation enables the identification of the need for modifying the track to achieve the settled objectives in case the progress is not fully satisfactory.

At the beginning of the policy cycle, indicators can provide a deeper orientation of where to add more resources or where to focus while designing a policy. They may allow a deeper understanding of some elements and even help to identify relations that may not be shown through basic statistics or data. Indicators, as communication instruments, can be useful tools for policymakers to express elaborated ideas or concepts to other relevant stakeholders of the sector or out of it; e.g., the indicators issued by national governments to inform regional or local authorities.

Indicators can also be differentiated by whether they are individual or composite (also known as aggregated). The first ones are commonly used to show the presence or state of a situation or condition individually for a topic [94]. Despite the usefulness of individual indicators, sometimes the information provided may not be enough for the purposes of the evaluation or an integrative assessment of more than one element. Hence, the condition of the state of a topic may require the evaluation of more than one criterion, requiring the use of composite indicators. For some interrelated information, composite indicators are a feasible alternative. They are the result of individual indicators being compiled into a single index to summarize complex and multi-dimensional situations [95]. Some well-known examples of composite indicators in the energy field are the energy poverty and energy access indicators. For energy deployment decisions, policymakers require to know the state of the energy sources, which involves different concerns. That may require an aggregated indicator. For this example, aggregated and individual indicators may be required to contribute to providing information about the energy sources, including why and how they were successful, the social perceptions around them, together with the economic details and other relevant concerns [24].

\subsection{Indicators Review Methodology}

The indicators' documents search was initially done in the open browser Google. The first 50 results of the search under energy policy indicators were reviewed in detail. Many of them were about energy or indicators, however, they either analyze or propose indicators related to buildings, 
utilities or other very specific topics of the energy sector or are not related to energy policies. Therefore, only the documents with general energy policy goals were considered, resulting in 23 documents presented in Appendix B.

Subsequently, a complementary search was done on the academic database Sciencedirect. From the first 50 documents retrieved under Energy Policy Indicators, most of the documents retrieved, do not propose new sets of indicators (from the ones previously identified). The majority of the related documents focus on analyzing the indicators proposals done by international organizations or governments (identified through the open sources search) or documents that focus on the analysis of the implementation of the indicators in a particular country or region.

When searching the corresponding indicators for every condensed concern through the retrieved documents, some concerns could not be matched through the recovered documents. A detailed search was done to find at least one indicator for the concerns. This led to finding additional documents listed in Appendix B. For this search, the concerns themselves were used as keywords, together with the term "indicator", "assessment" and "evaluation".

\subsection{Indicator Identification}

In Section 4 all the extracted concerns were organized into condensed concerns, for which the indicator identification process was followed, identifying, at least one indicator for every condensed concern. The end objective of each concern has been enlisted, and at least one indicator as an assessment metric of each objective has been identified.

Table 14 shows the indicators for the condensed concerns with an economic orientation. For all the concerns, more than one indicator has been identified.

Table 14. Identified indicators for the condensed concerns-Economic.

\begin{tabular}{|c|c|c|c|c|c|}
\hline Concern & End Objective & Indicator & Units & Source & Definition \\
\hline \multirow{2}{*}{ Affordability } & \multirow{2}{*}{$\begin{array}{l}\text { Max. The } \\
\text { capability of } \\
\text { energy payment }\end{array}$} & Willingness to Pay & $\begin{array}{l}\text { Numerical } \\
\text { value }\end{array}$ & $\begin{array}{c}\text { Measuring } \\
\text { Willingness to Pay } \\
\text { for Electricity [96] }\end{array}$ & $\begin{array}{l}\text { Indicator of how much } \\
\text { personal satisfaction or } \\
\text { well-being individuals } \\
\text { derive from } \\
\text { different outcomes }\end{array}$ \\
\hline & & $\begin{array}{c}\text { Spending on energy as a } \\
\text { proportion of the } \\
\text { household income }\end{array}$ & Percentage & $\begin{array}{l}\text { Assessing the } \\
\text { performance of } \\
\text { renewable energy } \\
\text { support policies } \\
\text { with quantitative } \\
\text { indicators [97]. }\end{array}$ & $\begin{array}{l}\text { Percentage of income } \\
\text { destined to pay } \\
\text { electric energy }\end{array}$ \\
\hline \multirow[b]{2}{*}{ Accessibility } & \multirow[b]{2}{*}{$\begin{array}{c}\text { Max. The } \\
\text { capability of } \\
\text { energy provision }\end{array}$} & Energy access & $\begin{array}{l}\text { Aggregated } \\
\text { value }\end{array}$ & $\begin{array}{l}\text { Energy Access } \\
\text { Score [98]. }\end{array}$ & $\begin{array}{l}\text { Aggregated indicator of } \\
\text { eight subindicators }\end{array}$ \\
\hline & & Energy security & $\begin{array}{c}\text { Vary by } \\
\text { subindicator }\end{array}$ & $\begin{array}{l}\text { Energy Trilemma } \\
\text { Index [99]. }\end{array}$ & $\begin{array}{l}\text { Indicator part of the } \\
\text { Energy Trilemma Index, } \\
\text { assessment of Security of } \\
\text { Supply and } \\
\text { Energy Delivery }\end{array}$ \\
\hline \multirow{3}{*}{$\begin{array}{c}\text { Economic } \\
\text { competitiveness }\end{array}$} & \multirow{3}{*}{$\begin{array}{l}\text { Max. The economic } \\
\text { competitiveness }\end{array}$} & $\begin{array}{c}\text { Harmonized } \\
\text { Competitiveness }\end{array}$ & $\begin{array}{l}\text { Numerical } \\
\text { value }\end{array}$ & $\begin{array}{l}\text { Harmonised } \\
\text { competitiveness } \\
\text { indicators [100]. }\end{array}$ & $\begin{array}{l}\text { Indicators that include } \\
\text { price and cost } \\
\text { competitiveness }\end{array}$ \\
\hline & & Competitiveness Index & Index & $\begin{array}{l}\text { The Global } \\
\text { Competitiveness } \\
\text { Report [101]. }\end{array}$ & $\begin{array}{l}\text { Index that analyzes } \\
\text { competitiveness along } \\
12 \text { pillars by country }\end{array}$ \\
\hline & & Country Context & $\begin{array}{c}\text { Vary by } \\
\text { subindicator }\end{array}$ & $\begin{array}{l}\text { Energy Trilemma } \\
\text { Index [99]. }\end{array}$ & $\begin{array}{l}\text { Part of the Energy } \\
\text { Trilemma Index. } \\
\text { Includes Investability, } \\
\text { Stable Regulatory } \\
\text { environment, Air, land } \\
\text { and water impact, } \\
\text { RD\&D and innovation, } \\
\text { Coherent and } \\
\text { predictable framework. }\end{array}$ \\
\hline
\end{tabular}


Table 15 shows the proposed indicators for the condensed concern with environmental orientation, environmental sustainability, for which three alternatives were identified; the proposed indicators for the two condensed concerns with social orientation are shown in Table 16; the indicators for the Governance effectiveness and efficacy condensed concern are shown in Table 17.

Table 15. Condensed Environmental Energy Policy Effectiveness concerns and identified indicators.

\begin{tabular}{|c|c|c|c|c|c|}
\hline Concern & End Objective & Indicator & Units & Source & Definition \\
\hline \multirow{3}{*}{$\begin{array}{l}\text { Environmental } \\
\text { sustainability }\end{array}$} & \multirow{3}{*}{$\begin{array}{l}\text { Min. The } \\
\text { environmental } \\
\text { impacts }\end{array}$} & $\begin{array}{c}\text { Environmental } \\
\text { Sustainability Indicator }\end{array}$ & $\begin{array}{l}\text { Vary by } \\
\text { indicator }\end{array}$ & $\begin{array}{l}\text { Environmental } \\
\text { Sustainability } \\
\text { Indicator [102]. }\end{array}$ & $\begin{array}{c}\text { Indicators on air, climate, } \\
\text { water, nature, } \\
\text { and human influence. }\end{array}$ \\
\hline & & $\begin{array}{c}\text { Environmental } \\
\text { Performance Index }\end{array}$ & Index & $\begin{array}{l}\text { Environmental } \\
\text { Performance } \\
\text { Index [103]. }\end{array}$ & $\begin{array}{l}\text { Ranks } 180 \text { countries on } \\
24 \text { performance } \\
\text { indicators across ten } \\
\text { issue categories covering } \\
\text { environmental health } \\
\text { and ecosystem vitality }\end{array}$ \\
\hline & & $\begin{array}{l}\text { Environmental } \\
\text { Sustainability }\end{array}$ & $\begin{array}{c}\text { Vary by } \\
\text { subindicator }\end{array}$ & $\begin{array}{l}\text { Energy Trilemma } \\
\text { Index [99]. }\end{array}$ & $\begin{array}{l}\text { Part of the Energy } \\
\text { Trilemma Index. } \\
\text { Includes the } \\
\text { assessment of Energy } \\
\text { resource productivity, } \\
\text { GHG Emission and } \\
\text { C02 emissions }\end{array}$ \\
\hline $\begin{array}{l}\text { Impact on climate } \\
\text { change }\end{array}$ & $\begin{array}{l}\text { Minimize the } \\
\text { impact on climate } \\
\text { change }\end{array}$ & $\begin{array}{l}\text { GHG emissions from } \\
\text { energy production per } \\
\text { unit of GDP }\end{array}$ & $\begin{array}{c}\text { GHG/GDP } \\
\text { (C02/economic } \\
\text { unit) }\end{array}$ & $\begin{array}{c}\text { Indicators for } \\
\text { Energy Sustainable } \\
\text { Development [89]. }\end{array}$ & $\begin{array}{l}\text { Composed by } \\
\text { GHG emissions from } \\
\text { energy production } \\
\text { over GDP }\end{array}$ \\
\hline
\end{tabular}

Table 16. Condensed Social Energy Policy Effectiveness concerns and identified indicators.

\begin{tabular}{|c|c|c|c|c|c|}
\hline Concern & End Objective & Indicator & Units & Source & Definition \\
\hline \multirow[b]{2}{*}{ Equity } & \multirow{2}{*}{$\begin{array}{l}\text { Max. the } \\
\text { consumer's welfare }\end{array}$} & Energy Equity Indicators & Vary by subindicator & $\begin{array}{l}\text { Energy Equity } \\
\text { Indicators [104]. }\end{array}$ & $\begin{array}{c}\text { Set of indicators that } \\
\text { evaluates Access, } \\
\text { investment and Resilience }\end{array}$ \\
\hline & & Energy Equity & Vary by subindicator & $\begin{array}{l}\text { Energy Trilemma } \\
\text { Index [99]. }\end{array}$ & $\begin{array}{l}\text { Includes the assessment of } \\
\text { Access, Quality of Supply } \\
\text { and Affordability } \\
\text { and competitiveness }\end{array}$ \\
\hline Health's impacts & $\begin{array}{l}\text { Min. The energy } \\
\text { impact on health }\end{array}$ & $\begin{array}{l}\text { Accident fatalities per } \\
\text { energy produced by } \\
\text { fuel chain }\end{array}$ & $\begin{array}{l}\text { Number of fatalities } \\
\text { by fuel chains per } \\
\text { energy or electricity } \\
\text { produced annually }\end{array}$ & $\begin{array}{l}\text { Energy indicators for } \\
\text { sustainable } \\
\text { development [87]. }\end{array}$ & $\begin{array}{l}\text { Annual fatalities by } \\
\text { fuel chain }\end{array}$ \\
\hline
\end{tabular}

Table 17. Condensed Governance Energy Policy Effectiveness concerns and identified indicators.

\begin{tabular}{|c|c|c|c|c|c|}
\hline Concern & End Objective & Indicator & Units & Source & Definition \\
\hline \multirow{2}{*}{$\begin{array}{l}\text { Governance } \\
\text { effectiveness } \\
\text { and efficacy }\end{array}$} & \multirow{2}{*}{$\begin{array}{l}\text { Max. the policy } \\
\text { effectiveness }\end{array}$} & $\begin{array}{l}\text { Institutional } \\
\text { Feasibility } \\
\text { indicators }\end{array}$ & Vary by subindicator & $\begin{array}{c}\text { Institutional } \\
\text { Feasibility } \\
\text { indicators [24]. }\end{array}$ & $\begin{array}{c}\text { Aggregated and } \\
\text { individual indicators for } \\
\text { six dimensions } \\
\text { of governance }\end{array}$ \\
\hline & & $\begin{array}{l}\text { Worldwide } \\
\text { Governance } \\
\text { Indicators }\end{array}$ & Percentile Rank (0 to 100) & $\begin{array}{c}\text { Worldwide } \\
\text { Governance } \\
\text { Indicators [105]. }\end{array}$ & $\begin{array}{c}\text { Indicators that Summarize } \\
\text { dataset of the quality } \\
\text { of governance }\end{array}$ \\
\hline
\end{tabular}

\section{Discussion}

\subsection{Contributions of the Review}

Wide variety of documents (66 documents) that meet the eligibility criteria have been analyzed. Each of them presents an alternative to characterize energy policies. The data gathered derives from multiple sources that attempt to give a solution to the same question: how to evaluate energy policy effectiveness?

The results generated a wider perspective on the different concerns that assess energy policy effectiveness. Four core categories (Economic, Environmental, Social, and Institutional) were organized and synthesized through more specific categories (eight condensed concerns organized by their ends objective), presented in Figure 2. 


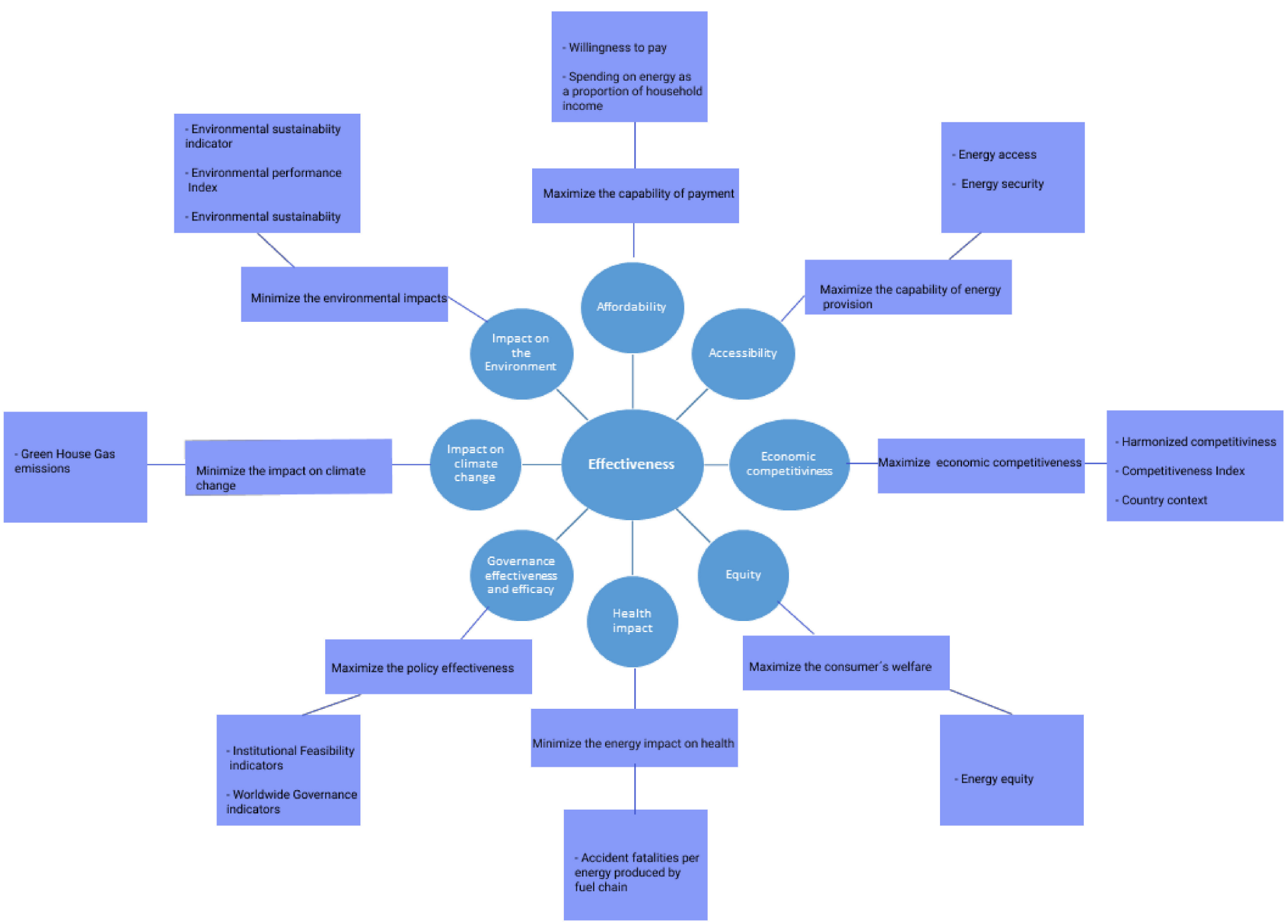

Figure 2. Effectiveness characterizing condensed concerns. 
It was found that five documents of the review [21,27,30,32,52] consider at least one extracted concern under each of the four core categories, being the most complete documents presented in this review. Nevertheless, no single document covered the seven condensed concerns that have been identified. Therefore, our results are an expansion of those approaches, giving the possibility to apply a more integral evaluation.

The identification of the core metrics of the concerns was also done, leading to the exploration of the energy policy indicators spectrum. The main contribution of this review is the organization of attributes focused on assessing energy policy effectiveness in a more detailed way. The Energy Trilemma [99] metrics have been very useful to identify options to assess some of the identified condensed concerns; however, the Trilemma lacks the consideration of one of the core categories resulting from this review, the Institutional one.

The potential of the data from this review gives the possibility to construct more complete and integral assessment procedures and to reframe already existing energy policy evaluation methodologies with the addition of new attributes (and its metrics).

This review can be directly useful for the national and international current governance situation, in which different levels of authority are implementing approaches for climate change mitigation, whereas EP evaluation is required, e.g., for the SDGs achievement assessment, a set of indicators currently exists [106]. However, a policy effectiveness evaluation tool or methodology (in coherence with the SDGs) may contribute to assess in more detail every policy. Therefore, this report contributes to establishing a base for the future development of a policy effectiveness evaluation methodology that supports the alignment of policies to achieve the SDGs or any other international, national, or local frameworks.

\subsection{Limitations of the Review}

The search considered the key search engines Elservier, Google, Google scholar, and JSTOR, so in principle, all major publications obeying the criteria were covered. However, theoretically, it could happen that the consideration of additional databases (e.g.,CORE, Bielefeld Academic Search Engine (BASE), Directory of Open Access Journals (DOAJ), Social Science Research Network (SSRN), World Wide Science, Semantic Scholar, etc.) could provide some additional results. In addition, the non-published documents (studies non-accepted for publication) have not been reviewed; however, this situation does not pose a serious threat to the validity of the review [107]. The search protocol applied has a reasonable degree of easiness and reachability, resulting in a sound number of documents that could be gathered.

The data generated is suitable to be analyzed with statistical methods or other quantitative techniques as HOMA [108] or MASEM [109]. Meta-analysis techniques have not been applied in this study, which has a qualitative nature. However, useful information may be retrieved in the future by such kind of analysis.

\section{Conclusions}

This review aimed to characterize the policy evaluation practices in the Energy field, with a focus on the metrics: concerns, objectives, and indicators. In addition to efficacy and efficiency, an emphasis was put into trying to find indicators that can assess effectiveness. Effectiveness enables a more holistic, field-tested, and modulated assessment of the achievements.

It was found that from the different categories (Environmental, Economic, Social, and Institutional), the Economic category is the one most often included, being present in nearly all documents (36 out of 66). Ex post is the most frequent evaluation type in terms of the moment (34 out of 66). Regarding the level of disaggregation reported for EP evaluations, local studies were found in three documents, while the national ones had the lead (40 out of 66). Considerations like the stakeholder's participation, evaluation motivation, and methodological approach varied with less focus across the gathered documents. 
The extracted concerns were condensed in a more compact list that eliminated redundancies, organizing them by their end objective. This resulted in seven condensed concerns: accessibility; affordability; competitiveness; impact on climate change; other impacts on the environment; equity; and health.

A total of 15 indicators were identified as possible alternatives to fully characterize the concerns: 2 for affordability, 2 for accessibility, 3 for economic competitiveness, 3 for environmental impacts, 2 for equity, 1 for health, and 2 for governance effectiveness and efficacy. This list is a considerable expansion from what could be found in any single previous document. It is proposed as a holistic assessment of the effectiveness of energy policies. The information organized through this review could be the object of further future works, e.g., on the computation of every single indicator-either ex ante or ex post, but with the goal of enabling ex ante estimation as much as possible. This would further support the elaboration of solid policies, adapted to the local institutional and geographical contexts.

Author Contributions: Conceptualization, V.L. and D.O.; formal analysis, D.O.; funding acquisition, D.O.; investigation, D.O.; methodology, D.O. and V.L.; supervision, V.L.; validation, D.O. and V.L. visualization, D.O.; writing-original draft, D.O.; writing-review and editing, D.O. and V.L. All authors have read and agreed to the published version of the manuscript.

Funding: This research was funded by the Consejo Nacional para la Ciencia y la Tecnología or Mexico, grant number 695470 within MIT SES Portugal Doctoral Program.

Conflicts of Interest: The authors declare no conflict of interest.

\section{Abbreviations}

$\begin{array}{ll}\text { EP } & \text { Energy Policy } \\ \text { GHG } & \text { Greenhouse Effect Gases } \\ \text { CBA } & \text { Cost-Benefit Analysis } \\ \text { ROA } & \text { Return on Assets } \\ \text { RE } & \text { Renewable Energy } \\ \text { GDP } & \text { Gross Domestic Product } \\ \text { MCDM } & \text { Multi-criteria Decision Making }\end{array}$

\section{Appendix A Identification of Documents by Search Terms}

Table A1. Energy policy evaluation documents adopted (Sciencedirect).

\begin{tabular}{|c|c|c|}
\hline$\#$ & Name of Document & Authors \\
\hline 1 & $\begin{array}{l}\text { Proposing an evaluation framework for energy policy making } \\
\text { incorporating equity: Applications in Australia }\end{array}$ & (Chapman et al., 2016a) [16]. \\
\hline 2 & An analytical framework for energy policy evaluation & (Chen, 2011) [18]. \\
\hline 3 & $\begin{array}{l}\text { Energy efficiency policy evaluation by moving } \\
\text { from techno-economic }\end{array}$ & (Bukarica \& Tomšić, 2017) [46]. \\
\hline 4 & $\begin{array}{c}\text { Why is South Korea's renewable energy policy failing? } \\
\text { A qualitative evaluation }\end{array}$ & (Yoon \& Sim, 2015) [77]. \\
\hline 5 & $\begin{array}{l}\text { A multiple perspective modeling and simulation approach for } \\
\text { renewable energy policy evaluation }\end{array}$ & $\begin{array}{l}\text { (Alyamani, Damgacioglu, Celik, } \\
\text { Asfour, \& Feiock, 2016) [19]. }\end{array}$ \\
\hline 6 & $\begin{array}{c}\text { Consumers' evaluation of national new energy vehicle policy } \\
\text { in China: An analysis based on a four paradigm model } \\
\text { perceptions of importance and satisfaction }\end{array}$ & (W. Li, Long, \& Chen, 2016) [68]. \\
\hline 7 & $\begin{array}{c}\text { Renewable energy policy evaluation using real option } \\
\text { model-The case of Taiwan }\end{array}$ & (Lee \& Shih, 2010) [20]. \\
\hline 8 & Analysis of energy end-use efficiency policy in Spain & (Collado \& Díaz, 2017) [47]. \\
\hline 9 & $\begin{array}{l}\text { Development and assessment of renewable energy policy } \\
\text { scenarios by } 2030 \text { for Bulgaria }\end{array}$ & (Nikolaev \& Konidari, 2017) [21]. \\
\hline
\end{tabular}


Table A2. Energy policy evaluation documents adopted (Google).

\begin{tabular}{cll}
\hline$\#$ & \multicolumn{1}{c}{ Number of Document } & \multicolumn{1}{c}{ Number of Document } \\
\hline 10 & $\begin{array}{l}\text { Residential solar PV policy: An analysis of impacts, successes, } \\
\text { and failures in the Australian case }\end{array}$ & (Chapman et al., 2016b) [17]. \\
\hline 11 & $\begin{array}{l}\text { Conceptual and empirical advances in analysing policy mixes } \\
\text { for energy }\end{array}$ & (Rogge, Kern, \& Howlett, 2017) [66]. \\
\hline 12 & $\begin{array}{l}\text { IRENA: Evaluating Renewable Energy Policy: A Review of } \\
\text { Criteria and Indicators for Assessment }\end{array}$ & $\begin{array}{l}\text { (IRENA, Nicholls, Mawhood, Gross, \& } \\
\text { Castillo-Castillo, 2014) [67]. }\end{array}$ \\
\hline 13 & $\begin{array}{l}\text { Strengthening the Energy Policy Making Process and } \\
\text { Sustainability Outcomes in the OECD through Policy Design }\end{array}$ & (Chapman et al, 2016c) [76]. \\
\hline 14 & $\begin{array}{l}\text { Moving Toward Energy Efficiency: A Results-Driven Analysis } \\
\text { of Utility Based Energy Efficiency Policies }\end{array}$ & (Theel \& Westgaard, 2017) [13]. \\
\hline 15 & $\begin{array}{l}\text { Evaluation of Energy Policy Instruments for the Adoption of } \\
\text { Renewable Energy: Case of Wind Energy in the Pacific } \\
\text { Northwest U.S. }\end{array}$ & (Abotah, 2015) [15]. \\
\hline 16 & $\begin{array}{l}\text { Climate and energy policy solutions for China } \\
\text { Evaluating Consistency in Environmental Policy Mixes } \\
\text { through Policy, Stakeholder, and Contextual Interactions }\end{array}$ & (Lieu et al., 2018) [14]. \\
\hline 18 & $\begin{array}{l}\text { A Framework for Energy Policy Evaluation and Improvement } \\
\text { Incorporating Quantified Social Equity }\end{array}$ & $\begin{array}{l}\text { (A.J. Chapman, 2016) [48]. } \\
\text { Evaluation of Hawaii's Renewable Energy Policy }\end{array}$ \\
\hline
\end{tabular}

Table A3. Energy Policy Assessment documents adopted (Sciencedirect).

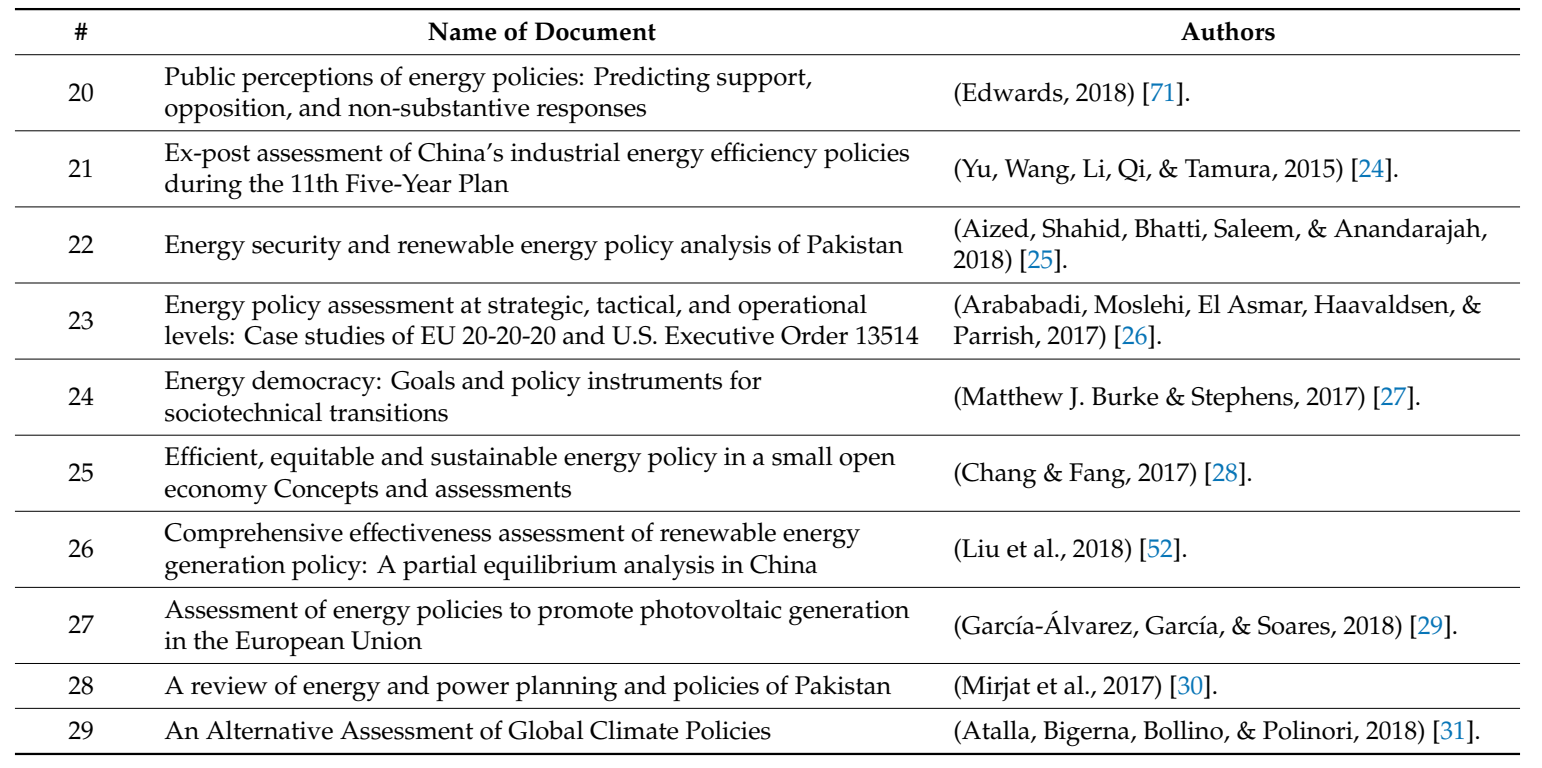

Table A4. Energy Policy Effectiveness documents adopted (Sciencedirect).

\begin{tabular}{clc}
\hline$\#$ & \multicolumn{1}{c}{ Name of Document } & \multicolumn{1}{c}{ Authors } \\
\hline 30 & $\begin{array}{l}\text { Effectiveness of policy incentives on electric vehicle acceptance in } \\
\text { China: A discrete choice analysis }\end{array}$ & (Wang, Tang, \& Pan, 2017) [69]. \\
\hline 31 & $\begin{array}{l}\text { Analysis of the effectiveness of national renewable energy policies: } \\
\text { A case of photovoltaic policies }\end{array}$ & (Hafeznia, Aslani, Anwar, \& Yousefjamali, 2017) [22]. \\
\hline 32 & $\begin{array}{l}\text { The effectiveness of China's wind power policy: } \\
\text { An empirical analysis }\end{array}$ & (X. Zhao, Li, Zhang, Yang, \& Liu, 2016) [49]. \\
\hline 33 & $\begin{array}{l}\text { The policy effectiveness of economic instruments for the } \\
\text { photovoltaic and wind power development in the European Union }\end{array}$ & (S. J. Li, Chang, \& Chang, 2017) [23]. \\
\hline 34 & The effectiveness of federal renewable policies in India & (Shrimali, Srinivasan, Goel, \& Nelson, 2017) [51]. \\
\hline
\end{tabular}


Table A5. Energy Policy Effectiveness documents adopted (Google scholar).

\begin{tabular}{|c|c|c|}
\hline$\#$ & Name of Document & Authors \\
\hline 35 & $\begin{array}{l}\text { Effectiveness of policy measures in transforming the energy } \\
\text { system }\end{array}$ & (Lund, 2007) [53]. \\
\hline 36 & $\begin{array}{l}\text { U.S. state policies for renewable energy: Context and } \\
\text { effectiveness }\end{array}$ & (Delmas \& Montes-sancho, 2011) [32]. \\
\hline 37 & $\begin{array}{l}\text { Which renewable energy policy is a venture capitalist's best } \\
\text { friend? Empirical evidence from a survey of international } \\
\text { cleantech investors }\end{array}$ & (B \& Rolf, 2009) [75]. \\
\hline 38 & $\begin{array}{l}\text { The effectiveness of different policy regimes for promoting } \\
\text { wind power: Experiences from the states }\end{array}$ & (Menz \& Vachon, 2006) [33]. \\
\hline 39 & $\begin{array}{l}\text { The effectiveness of European energy policy on the Italian } \\
\text { system: Regional evidences from a hierarchical cluster } \\
\text { analysis approach }\end{array}$ & (Arbolino, Boffardi, \& Ioppolo, 2019) [34]. \\
\hline 40 & $\begin{array}{l}\text { Analysing the effectiveness of renewable energy supporting } \\
\text { policies in the European Union }\end{array}$ & (Harmelink, Voogt, \& Crème,2006) [72]. \\
\hline 41 & The effectiveness of policy instruments in promoting bioenergy & (Thornley \& Cooper, 2008) [35]. \\
\hline 42 & $\begin{array}{l}\text { A quantile approach to assess the effectiveness of the subsidy } \\
\text { policy for energy-efficient home appliances: Evidence from } \\
\text { Rizhao, China }\end{array}$ & (Yao, Liu, \& Yan, 2014) [73]. \\
\hline 43 & $\begin{array}{l}\text { Assessing the strength and effectiveness of renewable } \\
\text { electricity feed-in tariffs in European Union countries }\end{array}$ & (Jenner, Groba, \& Indvik, 2013) [36]. \\
\hline 44 & $\begin{array}{l}\text { Feed-in tariff vs. renewable portfolio standard: An empirical } \\
\text { test of their relative effectiveness in promoting wind capacity } \\
\text { development }\end{array}$ & (Dong, 2012) [37]. \\
\hline 45 & $\begin{array}{l}\text { Wind electricity in Denmark: A survey of policies, their } \\
\text { effectiveness and factors motivating their introduction }\end{array}$ & (Agnolucci, 2007) [54]. \\
\hline 46 & $\begin{array}{l}\text { Effectiveness through risk reduction: a comparison of the } \\
\text { renewable obligation in England and Wales and the feed-in } \\
\text { system in Germany }\end{array}$ & (Mitchell, Bauknecht, \& Connor, 2006) [55]. \\
\hline 47 & $\begin{array}{l}\text { Double dividend effectiveness of energy tax policies and the } \\
\text { elasticity of substitution: A CGE appraisal }\end{array}$ & (Sancho, 2010) [38]. \\
\hline 48 & $\begin{array}{l}\text { Assessing the effectiveness of city-level electric vehicle policies } \\
\text { in China }\end{array}$ & (Qiu, Zhou, \& Sun, 2019) [56]. \\
\hline 49 & $\begin{array}{l}\text { Renewable energy policy effectiveness. A panel data analysis } \\
\text { across Europe and Latin America }\end{array}$ & (Menanteau \& El-methni, 2020) [39]. \\
\hline
\end{tabular}

Table A6. Energy Policy Effectiveness documents adopted (JSTOR).

\begin{tabular}{cll}
\hline$\#$ & \multicolumn{1}{c}{ Name of Document } & \multicolumn{1}{c}{ Authors } \\
\hline 50 & $\begin{array}{l}\text { Policy Effectiveness in Energy Conservation and } \\
\text { Emission Reduction }\end{array}$ & (Yuan et al, 2011) [57]. \\
\hline 51 & $\begin{array}{l}\text { An ex-ante evaluation of the EU Energy Efficiency } \\
\text { Directive-Article 7 }\end{array}$ & (Rosenow, Leguijt, Pato, \& Eyre, 2016) [58]. \\
\hline 52 & $\begin{array}{l}\text { Effectiveness, Implementation, and Policy Diffusion: Or “Can } \\
\text { We Make That Work for Us? }\end{array}$ & (Nicholson-crotty \& Carley, 2016) [59]. \\
\hline
\end{tabular}

Table A7. Energy Policy Evaluation documents adopted (Google Scholar).

\begin{tabular}{clc}
\hline$\#$ & \multicolumn{1}{c}{ Name of Document } & \multicolumn{1}{c}{ Authors } \\
\hline 53 & $\begin{array}{l}\text { Multicriteria evaluation and public participation: the case of } \\
\text { UK energy policy }\end{array}$ & (Stagl, 2006) [40]. \\
\hline 54 & $\begin{array}{l}\text { A real option model for renewable energy policy evaluation } \\
\text { with application to solar PV power generation in China }\end{array}$ & (Zhang, Zhou, \& Zhou, 2014) [60]. \\
\hline 55 & $\begin{array}{l}\text { Economic and Technological Models for Evaluation of Energy } \\
\text { Policy }\end{array}$ & (Hoffman et al., 1977) [41]. \\
\hline
\end{tabular}


Table A7. Cont.

\begin{tabular}{cll}
\hline$\#$ & \multicolumn{1}{c}{ Name of Document } & \multicolumn{1}{c}{ Authors } \\
\hline 56 & $\begin{array}{l}\text { State renewable energy electricity policies: An empirical } \\
\text { evaluation of effectiveness }\end{array}$ & (Carley, 2009) [42]. \\
\hline 57 & $\begin{array}{l}\text { Theory-based policy evaluation of 20 energy efficiency } \\
\text { instruments }\end{array}$ & (Harmelink, Nilsson, \& Harmsen, 2008) [76]. \\
\hline 58 & $\begin{array}{l}\text { Policy instruments fostering wind energy projects } \\
\text { multi-perspective evaluation approach }\end{array}$ & (Enzensberger, Wietschel, \& Rentz, 2002) [70]. \\
\hline 59 & $\begin{array}{l}\text { Outcome indicators for the evaluation of energy policy } \\
\text { instruments and technical change }\end{array}$ & (Neij \& Kerstin, 2006) [61]. \\
\hline 60 & $\begin{array}{l}\text { Hybrid agent-based simulation for policy evaluation of solar } \\
\text { power generation systems }\end{array}$ & (Zhao, Mazhari, Celik, \& Son, 2011) [62]. \\
\hline 61 & $\begin{array}{l}\text { The evaluation of renewable energy policies across EU } \\
\text { countries and US states: An econometric approach }\end{array}$ & (Kilinc-ata, 2016) [43]. \\
\hline 62 & $\begin{array}{l}\text { An evaluation of government incentives for new energy } \\
\text { vehicles in China focusing on vehicle purchasing restrictions }\end{array}$ & (Ma, Fan, \& Feng, 2020) [72]. \\
\hline 63 & $\begin{array}{l}\text { Performance evaluation of renewable energy support policies, } \\
\text { applied on Flanders' tradable certificates system }\end{array}$ & (Verbruggen, 2009) [63]. \\
\hline 64 & $\begin{array}{l}\text { Eco-labeling for energy efficiency and sustainability: a } \\
\text { meta-evaluation of US programs }\end{array}$ & (Banerjee \& Solomon, 2003) [64]. \\
\hline
\end{tabular}

Table A8. Energy Policy Evaluation documents adopted (JSTOR).

\begin{tabular}{clc}
\hline$\#$ & \multicolumn{1}{c}{ Name of Document } & \multicolumn{1}{c}{ Authors } \\
\hline 66 & $\begin{array}{l}\text { Taxing sulphur dioxide emissions: A policy evaluation from } \\
\text { public health perspective in China }\end{array}$ & (Ling-yun \& Jia-jia, 2016) [74]. \\
\hline
\end{tabular}

\section{Appendix B}

The indicators' documents with general energy policy goals from which the indicator identification analysis was initially done is presented in Table A9. The additional energy policy indicators' documents are registered in Table A10.

Table A9. List of documents for the Energy Policy Indicators analysis.

\begin{tabular}{|c|c|c|}
\hline Name & Issued by & Source \\
\hline Energy Indicators & Sustainable Energy Authority of Ireland & (Statistics, 2012) [85]. \\
\hline $\begin{array}{l}\text { Energy Indicators for Sustainable } \\
\text { Development: Country Studies }\end{array}$ & $\begin{array}{c}\text { International Atomic Energy Agency \& } \\
\text { United Nations Department of Economic and } \\
\text { Social Affairs }\end{array}$ & (IAEA et al., 2007) [86]. \\
\hline $\begin{array}{c}\text { Indicators for Energy Sustainable } \\
\text { Development Guidelines and Methodologies }\end{array}$ & $\begin{array}{c}\text { International Atomic Energy Agency \& World } \\
\text { Bank and Sustainable Energy for All }\end{array}$ & (IAEA et al., 2007) [87]. \\
\hline Energy Indicators & $\begin{array}{l}\text { Organization of the Petroleum } \\
\text { Exporting Countries }\end{array}$ & (OPEC, 2017) [89]. \\
\hline Energy indicators for electricity production & $\begin{array}{l}\text { Centre for Environmental Design of } \\
\text { Renewable Energy }\end{array}$ & (CEDREN, 2012) [90]. \\
\hline Renewable energy indicators 2013 & $\begin{array}{l}\text { The Global Carbon Capture and } \\
\text { Storage Institute }\end{array}$ & (Global CCS Institute, 2013) [91]. \\
\hline India Energy Indicators Index & $\begin{array}{l}\text { Ycharts, cloud-based investment } \\
\text { decision-making platform. }\end{array}$ & (Ycharts, 2018) [94]. \\
\hline New Zealand Energy Indicators & $\begin{array}{l}\text { Ministry of Business, } \\
\text { Innovation and Employment }\end{array}$ & (Business \& Employment, 2016) [95]. \\
\hline EEA energy and environment indicators & European Environmental Agency & (European Environmental Agency, 2005) [110]. \\
\hline UK Energy Sector Indicators 2015 & Department of Energy and Climate change & (DECC, 2015) [111]. \\
\hline
\end{tabular}


Table A9. Cont.

\begin{tabular}{ccc}
\hline Name & Issued by & Source \\
\hline Canada Energy Statistics & Statistics Canada & (Government of Canada, 2016) [112]. \\
\hline $\begin{array}{c}\text { Odysee Project Database(Indicators) } \\
\text { Indicators and potentials in buildings, } \\
\text { communities, and energy systems }\end{array}$ & Enerdata & (Enerdata, 2016) [113]. \\
\hline MENA-Energy Indicators (2017) & Consultancy Group & (Forsström et al., 2011) [114]. \\
\hline Sweden Energy Indicators & World Bank Group & (World Bank Group, 2017) [115]. \\
\hline $\begin{array}{c}\text { Regulatory Indicators for Sustainable Energy } \\
\text { Nordic Countries Energy Indicators }\end{array}$ & $\begin{array}{c}\text { Energy Sector Management } \\
\text { Assistance Program, World Bank }\end{array}$ & (Swedish Energy Agency, 2016) [116]. \\
\hline $\begin{array}{c}\text { Evaluating Renewable Energy } \\
\text { Policy: Indicators }\end{array}$ & Nordic Energy Research & (World Bank Group, 2018) [117]. \\
\hline $\begin{array}{c}\text { Energy efficiency and conservation indicators } \\
\text { in Yemen }\end{array}$ & International Renewable Energy Agency & (Nordic Energy Research, 2017) [118]. \\
\hline Measuring Economic Policy Uncertainty & Ali M. Al-Ashwal & (Al-Ashwal, 2016) [119]. \\
\hline
\end{tabular}

Table A10. Additional Energy Policy Indicators Documents list.

\begin{tabular}{|c|c|c|}
\hline Name & Issued by & Source \\
\hline Government at a Glance—2017 edition & $\begin{array}{c}\text { Organisation for Economic Co-operation and } \\
\text { Development }\end{array}$ & $(\mathrm{OECD}, 2017)[105]$ \\
\hline $\begin{array}{l}\text { Indicators of Effective Policy Development \& } \\
\text { Implementation }\end{array}$ & $\begin{array}{l}\text { Schoolwide Integrated Framework for } \\
\text { Transformation }\end{array}$ & (Stonemeier, Trader, Kaloi, \& Williams, 2016) [121]. \\
\hline Indicators for policy management & $\begin{array}{l}\text { Interagency (leaded by the United Nations } \\
\text { Development Programme) }\end{array}$ & (UNDP, 2005) [122]. \\
\hline Climate policy confidence indicator & $\begin{array}{l}\text { Grantham Research Institute on Climate } \\
\text { Change and indicators }\end{array}$ & (Mcdowall, Zenghelis, \& Drummond, 2016) [123]. \\
\hline Measuring Willingness to Pay for Electricity & Asian Development Bank & (Choynowski, 2002) [96]. \\
\hline World Energy Trilemma Index 2018 & World Energy Council & (World Energy Council, \&Wyman 2018) [99]. \\
\hline World Bank Data & The World Bank & (The World Bank, 2019) [124]. \\
\hline Harmonized Competitiveness Indicators (HCIs) & European Central Bank & (European Central Bank, 2019) [100]. \\
\hline Global Competitiveness Index & World Economic Forum & (World Economic Forum, 2018) [101]. \\
\hline Environmental Sustainability Indicator & Government of Canada & (Government of Canada, 2019) [102]. \\
\hline Electricity Access Data & World Bank & (The World Bank, 2019) [98]. \\
\hline Environmental Performance Index (EPI) & $\begin{array}{l}\text { Yale, Center for Environmental Law and } \\
\text { Policy and other int. organizations }\end{array}$ & (Yale, 2019) [103]. \\
\hline Energy Equity Indicators & California Energy Commission & (California Energy Commission, 2019) [125]. \\
\hline Greenhouse gas inventories & European Commission & (Maria, Dg, \& Eea, 2018) [126]. \\
\hline Mitigation Goal Standard & World Resource Institute & (Levin, Owen-, Dickinson, \& Barth, 2014) [127]. \\
\hline Policy and Action Standard & World Resource Institute & (Rich et al., 2015) [128]. \\
\hline Climate Action Tracker & $\begin{array}{c}\text { New Climate Institute, Ecofys and Climate } \\
\text { Analytic }\end{array}$ & (Climate Action Tracker, 2019) [129]. \\
\hline Baseline Emission Inventory & Covenant of Mayors & (Covenant of Mayors, 2010) [130]. \\
\hline $\begin{array}{l}\text { Environmental Protection Indicators for California } \\
\text { (EPIC) }\end{array}$ & $\begin{array}{l}\text { California Environmental Protection Agency, } \\
\text { the Resources Agency, the Department of } \\
\text { Health Services }\end{array}$ & $\begin{array}{l}\text { (California Environmental Protection Agency } \\
\text { (Cal/EPA), the Resources Agency, 2004) [131]. }\end{array}$ \\
\hline Renewables 2018 global status report & REN21 (a multi-stakeholder network) & (Hales, 2018) [132]. \\
\hline Cost-Effectiveness and Productivity KPIs & KPI Drafting Group & (KPI Drafting Group, 2001) [133]. \\
\hline $\begin{array}{l}\text { New and Renewable Technologies for Sustainable } \\
\text { Development Book }\end{array}$ & $\begin{array}{l}\text { Naim Hamdia Afgan and Maria Cristina } \\
\text { Ramos de Carvalho }\end{array}$ & (Afgan \& Carvalho, 2002) [134]. \\
\hline $\begin{array}{c}\text { New Energy Externalities Developments for } \\
\text { Sustainability }\end{array}$ & Paul Scherrer Institut & $\begin{array}{l}\text { (Stefan Hirschberg, Christian Bauer, Peter Burgherr, } \\
\text { Roberto Dones, Andrew Simons, 2008) [135]. }\end{array}$ \\
\hline $\begin{array}{l}\text { Sustainability and Financial Performance of } \\
\text { Companies in the Energy Sector in Romania }\end{array}$ & Dragos Paun & (Paun, 2017) [136]. \\
\hline $\begin{array}{l}\text { Consumers' willingness to pay for renewable } \\
\text { energy: A meta-regression analysis }\end{array}$ & Chunbo Ma et al. & (C. Ma, Rogers, Kragt, \& Zhang, 2016) [137]. \\
\hline $\begin{array}{l}\text { Assessing the performance of renewable energy } \\
\text { support policies with quantitative indicators }\end{array}$ & DIA-CORE Project & (Held et al., 2014) [97]. \\
\hline Energy Intensity Indicator & $\begin{array}{l}\text { U.S. Department of Energy's Office of Energy } \\
\text { Efficiency and Renewable Energy }\end{array}$ & $\begin{array}{l}\text { (Office of Energy Efficiency \& Renewable Energy, } \\
\text { 2019) [138]. }\end{array}$ \\
\hline Worldwide Governance Indicators & Kaufmann et al. & (Kaufmann et al., 2010) [104]. \\
\hline
\end{tabular}




\section{References}

1. UNFCCC. Reporting and Review under the Paris Agreement. 2020. Available online: https://unfccc. int/process-and-meetings/transparency-and-reporting/reporting-and-review-under-the-paris-agreement (accessed on 11 November 2020).

2. UNDRR. What is the Sendai Framework? 2020. Available online: https://www.undrr.org/implementingsendai-framework/what-sendai-framework (accessed on 9 November 2020).

3. Berlin.de. Climate-Neutral Berlin 2050. 2020. Available online: https://www.berlin.de/sen/uvk/en/climateprotection/climate-neutral-berlin-2050/ (accessed on 26 October 2020).

4. The City of Ann Arbor. Ann Arbor's Living Carbon Neutrality Plan; Ann Arbor City Council: Ann Arbor, MI, USA, 2020.

5. Bayside City Council. Carbon Neutrality Action Plan 2018-2020; Bayside City Council: Bayside City, VIC, Australia, 2017.

6. Umwelt und Natur/Green City/Climate Protection/Climate-Neutral City. Climate-Neutral City. 2020. Available online: https://www.freiburg.de/pb/Len/642986.html (accessed on 26 October 2020).

7. UNFCCC. Action on Climate and SDGs. 2020. Available online: https://unfccc.int/topics/action-on-climateand-sdgs/action-on-climate-and-sdgs (accessed on 18 September 2020).

8. Parsons, J. Indicators of Inputs, Activities, Outputs, Outcomes and Impacts in Security and Justice Programming; Practice Products for the CCVRI; Conflict, Crime, and Violence Results Initiative: London, UK, 2013; pp. 1-29.

9. Cambridge Dictionary. Success. 2018. Available online: https://dictionary.cambridge.org/es-LA/dictionary/ essential-british-english/success (accessed on 12 September 2018).

10. Cambridge Dictionary. Efficacy. 2018. Available online: https://dictionary.cambridge.org/es-LA/dictionary/ essential-british-english/efficacy (accessed on 12 September 2018).

11. Cambridge Dictionary. Effectiveness. 2018. Available online: https://dictionary.cambridge.org/esLA/ dictionary/essential-british-english/effectiveness (accessed on 12 September 2018).

12. Ernst, E.; Pittler, M.H. Efficacy or effectiveness? J. Intern. Med. 2006, 260, 488-490. [CrossRef]

13. Theel, S.; Westgaard, A. Moving Toward Energy Efficiency: A Results-Driven Analysis of Utility-Based Energy Efficiency Policies. 2017. Available online: http://search.proquest.com.ezproxy.psz.utm.my/docview/ 272082138?pqorigsite=summon (accessed on 3 February 2018).

14. Lieu, J.; Spyridaki, N.A.; Alvarez-Tinoco, R.; van der Gaast, W.; Tuerk, A.; van Vliet, O. Evaluating consistency in environmental policy mixes through policy, stakeholder, and contextual interactions. Sustainability 2018, 10, 1896. [CrossRef]

15. Abotah, R. Evaluation of Energy Policy Instruments for the Adoption of Renewable Energy: Case of Wind Energy in the Pacific Northwest US; Portland State University: Portland, OR, USA, 2015; p. 282.

16. Chapman, A.J.; McLellan, B.; Tezuka, T. Residential solar PV policy: An analysis of impacts, successes and failures in the Australian case. Renew. Energy 2016, 86, 1265-1279. [CrossRef]

17. Chapman, A.J.; McLellan, B.; Tezuka, T. Proposing an evaluation framework for energy policy making incorporating equity: Applications in Australia. Energy Res. Soc. Sci. 2016, 21, 54-69. [CrossRef]

18. Chen, C.C. An analytical framework for energy policy evaluation. Renew. Energy 2011, 36, $2694-2702$. [CrossRef]

19. Alyamani, T.; Damgacioglu, H.; Celik, N.; Asfour, S.; Feiock, R. A multiple perspective modeling and simulation approach for renewable energy policy evaluation. Comput. Ind. Eng. 2016, 102, $280-293$. [CrossRef]

20. Lee, S.C.; Shih, L.H. Renewable energy policy evaluation using real option model—The case of Taiwan. Energy Econ. 2010, 32 (Suppl. S1), S67-S78. [CrossRef]

21. Nikolaev, A.; Konidari, P. Development and assessment of renewable energy policy scenarios by 2030 for Bulgaria. Renew. Energy 2017, 111, 792-802. [CrossRef]

22. Hafeznia, H.; Aslani, A.; Anwar, S.; Yousefjamali, M. Analysis of the effectiveness of national renewable energy policies: A case of photovoltaic policies. Renew. Sustain. Energy Rev. 2017, 79, 669-680. [CrossRef]

23. Li, S.J.; Chang, T.H.; Chang, S.L. The policy effectiveness of economic instruments for the photovoltaic and wind power development in the European Union. Renew. Energy 2017, 101, 660-666. [CrossRef]

24. Yu, Y.; Wang, X.; Li, H.; Qi, Y.; Tamura, K. Ex-post assessment of China's industrial energy efficiency policies during the 11th Five-Year Plan. Energy Policy 2015, 76, 132-145. [CrossRef] 
25. Aized, T.; Shahid, M.; Bhatti, A.A.; Saleem, M.; Anandarajah, G. Energy security and renewable energy policy analysis of Pakistan. Renew. Sustain. Energy Rev. 2018, 84, 155-169. [CrossRef]

26. Arababadi, R.; Moslehi, S.; El Asmar, M.; Haavaldsen, T.; Parrish, K. Energy policy assessment at strategic, tactical, and operational levels: Case studies of EU 20-20-20 and U.S. Executive Order 13514. Energy Policy 2017, 109, 530-538. [CrossRef]

27. Burke Matthew, J.; Stephens, J.C. Energy democracy: Goals and policy instruments for sociotechnical transitions. Energy Res. Soc. Sci. 2017, 33, 35-48. [CrossRef]

28. Chang, Y.; Fang, Z. Efficient, equitable and sustainable energy policy in a small open economy: Concepts and assessments. Energy Policy 2017, 105, 493-501. [CrossRef]

29. García-Álvarez, M.T.; García, L.C.; Soares, I. Assessment of energy policies to promote photovoltaic generation in the European Union. Energy 2018. [CrossRef]

30. Mirjat, N.H.; Uqaili, M.A.; Harijan, K.; Valasai, G.; Das Shaikh, F.; Waris, M. A review of energy and power planning and policies of Pakistan. Renew. Sustain. Energy Rev. 2017, 79, 110-127. [CrossRef]

31. Atalla, T.; Bigerna, S.; Bollino, C.A.; Polinori, P. An alternative assessment of global climate policies. J. Policy Model. 2018. [CrossRef]

32. Delmas, M.A.; Montes-sancho, M.J. US state policies for renewable energy: Context and effectiveness. Energy Policy 2011, 39, 2273-2288. [CrossRef]

33. Menz, F.C.; Vachon, S. The effectiveness of different policy regimes for promoting wind power: Experiences from the states. Energy Policy 2006, 34, 1786-1796. [CrossRef]

34. Arbolino, R.; Boffardi, R.; Ioppolo, G. The effectiveness of European energy policy on the Italian system: Regional evidences from a hierarchical cluster analysis approach. Energy Policy 2019, 132, 47-61. [CrossRef]

35. Thornley, P.; Cooper, D. The effectiveness of policy instruments in promoting bioenergy. Biomass Bioenergy 2008, 32, 903-913. [CrossRef]

36. Jenner, S.; Groba, F.; Indvik, J. Assessing the strength and effectiveness of renewable electricity feed-in tariffs in European Union countries. Energy Policy 2013, 52, 385-401. [CrossRef]

37. Dong, C.G. Feed-in tariff vs. renewable portfolio standard: An empirical test of their relative effectiveness in promoting wind capacity development. Energy Policy 2012, 42, 476-485. [CrossRef]

38. Sancho, F. Double dividend effectiveness of energy tax policies and the elasticity of substitution: A CGE appraisal. Energy Policy 2010, 38, 2927-2933. [CrossRef]

39. Bersalli, G.; Menanteau, P.; El-methni, J. Renewable energy policy effectiveness: A panel data analysis across Europe and Latin America. Renew. Sustain. Energy Rev. 2020, 133. [CrossRef]

40. Stagl, S. Multicriteria evaluation and public participation: The case of UK energy policy. Land Use Policy 2006, 23, 53-62. [CrossRef]

41. Hoffman, K.C.; Jorgenson, D.W.; The, S.; Journal, B.; Autumn, N.; Hoffman, K.C. Economic and technological models for evaluation of energy policy published. Bell. J. Econ. 1977, 8, 444-466. [CrossRef]

42. Carley, S. State renewable energy electricity policies: An empirical evaluation of effectiveness. Energy Policy 2009, 37, 3071-3081. [CrossRef]

43. Kilinc-ata, N. Energy for sustainable development the evaluation of renewable energy policies across EU countries and US states: An econometric approach. Energy Sustain. Dev. 2016, 31, 83-90. [CrossRef]

44. Qiang, L.; Chuan, T.; Xiaoqi, Z.; Kejun, J.; Chenmin, H.; Harvey, H.; Aggarwal, S.; Busch, C.; Rissman, J.; Orvis, R.; et al. Climate and Energy Policy Solutions for China Quantitative Analysis and Policy Recommendations for the 13Th Five-Year Plan. 2016. Available online: https://energyinnovation.org/wpcontent/uploads/2016/07/ChinaPolicySolutions_ExecutiveSummary_EN.pdf (accessed on 22 February 2018).

45. Energy and Environmental Economics. Evaluation of Hawaii's Renewable Energy Policy and Procurement; Energy and Environmental Economics, Inc.: San Francisco, CA, USA, 2014.

46. Bukarica, V.; Tomšić, Ž. Energy efficiency policy evaluation by moving from techno-economic towards whole society perspective on energy efficiency market. Renew. Sustain. Energy Rev. 2017, 70, 968-975. [CrossRef]

47. Collado, R.R.; Díaz, M.T.S. Analysis of energy end-use efficiency policy in Spain. Energy Policy 2017, 101, 436-446. [CrossRef]

48. Chapman, A.J. A Framework for Energy Policy Evaluation and Improvement Incorporating Quantified Social Equity. Ph.D. Thesis, Kyoto University, Kyoto, Japan, 2016.

49. Zhao, X.; Li, S.; Zhang, S.; Yang, R.; Liu, S. The effectiveness of China's wind power policy: An empirical analysis. Energy Policy 2016, 95, 269-279. [CrossRef] 
50. Ma, S.; Fan, Y.; Feng, L. An evaluation of government incentives for new energy vehicles in China focusing on vehicle purchasing restrictions. Energy Policy 2020, 110, 609-618. [CrossRef]

51. Shrimali, G.; Srinivasan, S.; Goel, S.; Nelson, D. The effectiveness of federal renewable policies in India. Renew. Sustain. Energy Rev. 2017, 70, 538-550. [CrossRef]

52. Liu, D.; Liu, M.; Xu, E.; Pang, B.; Guo, X.; Xiao, B.; Niu, D. Comprehensive effectiveness assessment of renewable energy generation policy: A partial equilibrium analysis in China. Energy Policy 2018, 115, 330-341. [CrossRef]

53. Lund, P.D. Effectiveness of policy measures in transforming the energy system. Energy Policy 2007, 627-639. [CrossRef]

54. Agnolucci, P. Wind electricity in Denmark: A survey of policies, their effectiveness and factors motivating their introduction. Renew. Sustain. Energy Rev. 2007, 11, 951-963. [CrossRef]

55. Mitchell, C.; Bauknecht, D.; Connor, P.M. Effectiveness through risk reduction: A comparison of the renewable obligation in England and Wales and the feed-in system in Germany. Energy Policy 2006, 34, 297-305. [CrossRef]

56. Qiu, Y.Q.; Zhou, P.; Sun, H.C. Assessing the effectiveness of city-level electric vehicle policies in China. Energy Policy 2019, 130, 22-31. [CrossRef]

57. Yuan, M.; Tuladhar, S.; Bernstein, P.; Lane, L. Policy Effectiveness in Energy Conservation and Emission Reduction. Strategies for Mitigating Climate Chang. Energy J. 2011, 32, 153-172. [CrossRef]

58. Rosenow, J.A.N.; Leguijt, C.O.R.; Pato, Z.; Eyre, N. An ex-ante evaluation of the EU Energy Efficiency Directive-Article 7. Econ. Energy Environ. Policy 2016, 5, 45-64. [CrossRef]

59. Nicholson-Crotty, A.S.; Carley, S. Effectiveness, Implementation, and Policy Diffusion: Or "Can We Make That Work for Us?". State Polit. Policy Q. 2016, 16, 78-97. [CrossRef]

60. Zhang, M.; Zhou, D.; Zhou, P. A real option model for renewable energy policy evaluation with application to solar PV power generation in China. Renew. Sustain. Energy Rev. 2014, 40, 944-955. [CrossRef]

61. Neij, L.; Kerstin, A. Outcome indicators for the evaluation of energy policy instruments and technical change. Energy Policy 2006, 34, 2662-2676. [CrossRef]

62. Zhao, J.; Mazhari, E.; Celik, N.; Son, Y. Simulation Modelling Practice and Theory Hybrid agent-based simulation for policy evaluation of solar power generation systems. Simul. Model. Pract. Theory 2011, 19, 2189-2205. [CrossRef]

63. Verbruggen, A. Performance evaluation of renewable energy support policies, applied on. Energy Policy 2009, 37, 1385-1394. [CrossRef]

64. Banerjee, A.; Solomon, B.D. Eco-labeling for energy efficiency and sustainability: A meta-evaluation of US programs. Energy Policy 2003, 31, 109-123. [CrossRef]

65. Kim, K.; Lee, C. Evaluation and optimization of feed-in tariffs. Energy Policy 2012, 49, 192-203. [CrossRef]

66. Rogge, K.S.; Kern, F.; Howlett, M. Conceptual and empirical advances in analysing policy mixes for energy transitions. Energy Res. Soc. Sci. 2017, 33, 1-10. [CrossRef]

67. Nicholls, J.; Mawhood, R.; Gross, R.; Castillo-Castillo, A.; IRENA. Evaluating Renewable Energy Policy: A Review of Criteria and Indicators for Assessment. 2014. Available online: http://www.irena.org/ documentdownloads/publications/evaluating_re_policy.pdf (accessed on 18 January 2019).

68. Li, W.; Long, R.; Chen, H. Consumers' evaluation of national new energy vehicle policy in China: An analysis based on a four paradigm model. Energy Policy 2016, 99, 33-41. [CrossRef]

69. Wang, N.; Tang, L.; Pan, H. Effectiveness of policy incentives on electric vehicle acceptance in China: A discrete choice analysis. Transp. Res. Part. A Policy Pract. 2017, 105, 210-218. [CrossRef]

70. Enzensberger, N.; Wietschel, M.; Rentz, O. Policy instruments fostering wind energy projects a multi-perspective evaluation approach. Energy Policy 2002, 30, 793-801. [CrossRef]

71. Edwards, M.L. Public perceptions of energy policies: Predicting support, opposition, and nonsubstantive responses. Energy Policy 2018, 117, 348-357. [CrossRef]

72. Harmelink, M.; Voogt, M.; Cremer, C. Analysing the effectiveness of renewable energy supporting policies in the European Union. Energy Policy 2006, 34, 343-351. [CrossRef]

73. Yao, X.; Liu, Y.; Yan, X. Short Communication A quantile approach to assess the effectiveness of the subsidy policy for energy-ef fi cient home appliances: Evidence from Rizhao, China. Energy Policy 2014, 73, 512-518. [CrossRef] 
74. Ling-Yun, H.E.; Jia-Jia, O.U. Taxing sulphur dioxide emissions: A policy evaluation from public health perspective in China. Energy Environ. 2016, 27, 755-764. [CrossRef]

75. Bürer, M.J.; Wüstenhagen, R. Which renewable energy policy is a venture capitalist's best friend? Empirical evidence from a survey of international cleantech investors. Energy Policy 2009, 37, 4997-5006. [CrossRef]

76. Chapman, A.; Mclellan, B.; Tezuka, T. Administrative sciences Strengthening the Energy Policy Making Process and Sustainability Outcomes in the OECD through Policy Design. Adm. Sci. 2016, 6, 9. [CrossRef]

77. Yoon, J.H.; Sim, K. Why is South Korea's renewable energy policy failing? A qualitative evaluation. Energy Policy 2015, 86, 369-379. [CrossRef]

78. Harmelink, M.; Nilsson, L.; Harmsen, R. Theory-based policy evaluation of 20 energy efficiency instruments. Energy Effic. 2008, 131-148. [CrossRef]

79. Cambridge Dictionary. Affordability. 2019. Available online: https://dictionary.cambridge.org/es-LA/ dictionary/english/affordability (accessed on 12 September 2019).

80. Cambridge Dictionary. Accessibility. 2019. Available online: https://dictionary.cambridge.org/es-LA/ dictionary/english/accessibility (accessed on 12 September 2019).

81. Cambridge Dictionary. Competitiveness. 2019. Available online: https://dictionary.cambridge.org/es-LA/ dictionary/english/competitiveness (accessed on 12 September 2019).

82. Cambridge Dictionary. Environmental Sustainability. 2019. Available online: https://dictionary.cambridge. org/es-LA/dictionary/english/environmentalsustainability (accessed on 12 September 2019).

83. Cambridge Dictionary. Equity. 2019. Available online: https://dictionary.cambridge.org/es-LA/dictionary/ english/equity (accessed on 12 September 2019).

84. Cambridge Dictionary. Governance. 2019. Available online: https://dictionary.cambridge.org/es-LA/ dictionary/english/goverance (accessed on 12 September 2019).

85. Sustainable Energy Authority of Ireland. Energy in Ireland; Sustainable Energy Authority of Ireland: Dublin, Ireland, 2018.

86. IAEA; UNDESA; IEA; EUROSTAT; EEA. Energy indicators for sustainable development: Guidelines and Methodologies. Energy 2007, 32, 875-882. [CrossRef]

87. International Atomic Energy Agency; United Nations Department of Economic and Social Affairs. Energy Indicators for Sustainable Development: Country Studies; International Atomic Energy Agency: Paris, France; United Nations Department of Economic and Social Affairs: Rome, Italy, 2007; p. 463.

88. Eurostat. Energy, Transport and Environment Indicators, 2017 ed.; Eurostat Pocketbook; Eurostat: Luxembourg, 2017; Volume 25, ISBN 978-92-79-74192-0. [CrossRef]

89. OPEC. Market Indicators. 2017. Available online: http://www.opec.org/opec_web/en/data_graphs/4080.htm (accessed on 12 September 2018).

90. CEDREN. Energy Indicators for Electricity Production Comparing Technologies; Centre for Environmental Design of Renewable Energy: Trondheim, Norway; DN (Directorate for Nature Management): Trondheim, Norway, 2012.

91. Global CCS Institute. Renewable Energy Indicators 2013. Global CCS Institute: 2013. Available online: https://hub.globalccsinstitute.com/publications/renewables-2014-global-status-report/renewableenergy-indicators-2013 (accessed on 25 May 2018).

92. World Energy Council. Energy Efficiency Indicators. 2016. Available online: https://www.worldenergy.org/ data/efficiency-indicators/ (accessed on 28 May 2018).

93. International Energy Agency. Energy Efficiency Indicators: Fundamentals on Statistics; IEA: Paris, France, 2014.

94. Ycharts. India Energy Indicators. 2018. Available online: https://ycharts.com/indicators/regions/countries/ IND/indicators? category=energy (accessed on 7 June 2018).

95. Ministry of Business, Innovation \& Employment in New Zealand 2016, 69. 2016. Available online: http://ci.nii.ac.jp/naid/40020762305/ (accessed on 8 September 2018).

96. Choynowski, P. Measuring Willingness to Pay for Electricity; Asian Development Bank: Manila, Philippines, 2002.

97. Held, A.; Ragwitz, M.; Boie, I.; Wigand, F.; Janeiro, L.; Klessmann, C.; Nabe, C.; Hussy, C.; Neuhoff, K.; Grau, T.; et al. Assessing the Performance of Renewable Energy Support Policies with Quantitative Indicators; Fraunhofer ISI: Karlshöhe, Germany, 2014.

98. World Bank. World Bank Data. 2019. Available online: https://data.worldbank.org/indicator (accessed on 30 January 2019).

99. Wyman, O.; World Energy Council. World Energy Trilemma Index; World Energy Council: London, UK, 2018. 
100. European Central Bank. Harmonised Competitiveness Indicators. 2019. Available online: https://data. europa.eu/euodp/en/data/dataset/ecb-competitiveness-indicators (accessed on 30 January 2019).

101. Schwab, K.; World Economic Forum. The Global Competitiveness Report; World Economic Forum: Geneva, Switzerland, 2018.

102. Government of Canada. Environmental Indicators-Canada.Ca. 2019. Available online: https://www.canada. ca/en/environment-climate-change/services/environmental-indicators.html (accessed on 25 January 2019).

103. Yale. Introduction|Environmental Performance Index. 2019. Available online: https://epi.envirocenter.yale. edu/2018-epi-report/introduction (accessed on 8 January 2019).

104. Kaufmann, D.; Kraay, A.; Mastruzzi, M. The Worldwide Governance Indicators: Methodology and Analytical Issues; The Worlwide Governance Indicators: Washington, DC, USA; Geneva, Switzerland, 2010.

105. OECD. Goverment at Glance 2017; OECD Publishing: Paris, France, 2017.

106. SDG Indicators. SDG Indicators. 2020. Available online: https://unstats.un.org/sdgs/indicators/indicators-list/ (accessed on 18 September 2020).

107. Dalton, D.R.; Aguinis, H.; Dalton, C.M.; Bosco, F.A.; Pierce, C.A. Revisiting the file drawer problem in meta-analysis: An Assessment of published and non-published correlation matrices. Pers. Psychol. 2012, 65, 221-249. [CrossRef]

108. Hedges, L.V.; Olkin, I. Statistical Methods for Meta-Analysis. J. Educ. Stat. 1985, 13, 75. [CrossRef]

109. Bergh, D.D.; Aguinis, H.; Heavey, C.; Ketchen, D.J.; Boyd, B.K.; Su, P.; Joo, H. Using meta-analytic structural equation modeling to advance strategic management research: Guidelines and an empirical illustration via the strategic leadership-performance relationship. Strateg. Manag. J. 2016, 37, 477-497. [CrossRef]

110. European Environmental Agency. EEA Core Set of Indicators; European Environmental Agency: Copenhagen, Denmark, 2005. [CrossRef]

111. DECC. UK Energy Sector Indicators 2015, 102. 2015. Available online: https://www.gov.uk/government/ statistics/uk-energy-sector-indicators-2015 (accessed on 25 September 2018).

112. Government of Canada. About Environmental Sustainability Indicators-Canada.ca. 2016. Available online: https://www.canada.ca/en/environment-climate-change/services/environmental-indicators/aboutsustainability.html (accessed on 7 January 2019).

113. Enerdata. Free Energy Indicators|ODYSSEE. 2016. Available online: http://www.indicators.odyssee-mure. eu/online-indicators.html (accessed on 12 January 2019).

114. Forsström, J.; Lahti, P.; Pursiheimo, E.; Rämä, M.; Shemeikka, J.; Sipilä, K.; Tuominen, P.; Wahlgren, I. Measuring Energy Efficiency: Indicators and Potentials in Buildings, Communities and Energy Systems; VTT Tiedotteita-Valtion Teknillinen Tutkimuskesku: Espoo, Finland, 2011.

115. World Bank Group. MENA-Energy Indicators-Datasets-Energydata.Info. 2017. Available online: https: //energydata.info/dataset/mena-energy-indicators-2017 (accessed on 15 January 2019).

116. Swedish Energy Agency. Energy Indicators in Figures 2016-Follow-up of Sweden's Energy Policy Goals. 2016. Available online: http://www.energimyndigheten.se/en/news/2016/energy-indicators-in-figures-2016--follow-up-of-swedens-energy-policy-goals/ (accessed on 25 January 2019).

117. World Bank Group. Indicators|RISE. 2018. Available online: http://rise.esmap.org/indicators (accessed on 14 January 2019).

118. Nordic Energy Research. Indicators-Nordic Energy Research. 2017. Available online: http://www.nordicenergy. org/indicators/ (accessed on 18 January 2019).

119. Al-Ashwal, A.M. Future Cities and Environment; Springer Open: Luxembourg, 2016. [CrossRef]

120. Baker, S.R.; Bloom, N.; Davis, S.J. Measuring Economic Policy Uncertainty. Q. J. Econ. 2016, 131, $1593-1636$. [CrossRef]

121. Stonemeier, B.J.; Trader, B.; Kaloi, L.; Williams, G. Indicators of Effective Policy Development E Implementation; SWIFT Center: Lawrence, NY, USA, 2016; pp. 1-7.

122. UNDP. Indicators for Policy Management; United Nations: New York, NY, USA, 2005.

123. Mcdowall, W.; Zenghelis, D.; Drummond, P. Climate Policy Confidence Indicator: Final Report to CCCEP; Grantham Research Institute on Climate Change and the Environment: London, UK, 2016.

124. The World Bank. Access to Electricity (\% of Population)|Data. 2019. Available online: https://data.worldbank. org/indicator/eg.elc.accs.zs (accessed on 29 January 2019).

125. California Energy Commission. Energy Equity Indicators. 2019. Available online: https://www.energy.ca. gov/sb350/barriers_report/equity-indicators.html (accessed on 10 January 2019). 
126. Maria, A.; Dg, D.; Eea, R.F. EEA Report/2018 Annual European Union Greenhouse Gas Inventory 1990-2016 and Inventory Report 2018 Submission to the UNFCCC Secretariat; European Environment Agency: Luxembourg, 2018.

127. Levin, K.; Owen, R.; Dickinson, J.; Barth, K.-K. Mitigation Goal Standard; World Resources Institute: Washington, DC, USA, 2014.

128. Rich, D.; Finnegan, J.; Owen-Jones, R.; García-Guerrero, A.; Dickinson, J.; Barth, K. Policy and Action Standard; World Resources Institute: Washington, DC, USA, 2015.

129. Climate Action Tracker. Scaling Up Climate Action Series|Climate Action Tracker. 2019. Available online: https://climateactiontracker.org/publications/scalingup/ (accessed on 24 January 2019).

130. Covenant of Mayors. How to Develop a Sustainable Energy Action Plan; Covenant of Mayors: Brussels, Belgium, 2010.

131. California Environmental Protection Agency (Cal/EPA) the Resources Agency; Department of Health Services. Environmental Protection Indicators for California (EPIC); California Environmental Protection Agency: Sacramento, CA, USA, 2004.

132. Hales, D. Renewables 2018 Global Status Report; Renewable Energy Policy Network for the 21st Century: Paris, France, 2018.

133. KPI Drafting Group. Working Paper Cost Effectiveness and Productivity KPIs; Version 1; EUROCONTROL: Brussels, Belgium, 2001.

134. Afgan, N.H.; de Carvalho, M.C.R. New and Renewable Technologies for Sustainable Development; Springer Science \& Business: New York, NY, USA, 2002.

135. Hirschberg, S.; Bauer, C.; Burgherr, P.; Dones, R.; Simons, A.; Bachmann, T.; Carrera, D.G. New Energy Externalities Developments for Sustainability. Deliverable $n^{\circ}$ D3. 2-RS $2 b$ Final Set of Sustainability Criteria and Indicators for Assessment of Electricity Supply Options; Paul Scherrer Institut: Villigen, Switzerland, 2008.

136. Paun, D. Sustainability and Financial Performance of Companies in the Energy Sector in Romania. Sustainability 2017, 9, 1722. [CrossRef]

137. Ma, C.; Rogers, A.A.; Kragt, M.E.; Zhang, F.F.; Polyakov, M.; Gibson, F.; Chalak, M.; Pandit, R.; Tapsuwan, S. Consumer Willingness to Pay for Renewable Energy: A Meta Analysis. Master's Thesis, Norwegian University of Life Sciences, Ås, Norway, 2015.

138. Office of Energy Efficiency \& Renewable Energy. Energy Intensity Indicators|Department of Energy. 2019. Available online: https://www.energy.gov/eere/analysis/energy-intensity-indicators (accessed on 13 January 2019).

Publisher's Note: MDPI stays neutral with regard to jurisdictional claims in published maps and institutional affiliations.

(C) 2020 by the authors. Licensee MDPI, Basel, Switzerland. This article is an open access article distributed under the terms and conditions of the Creative Commons Attribution (CC BY) license (http://creativecommons.org/licenses/by/4.0/). 